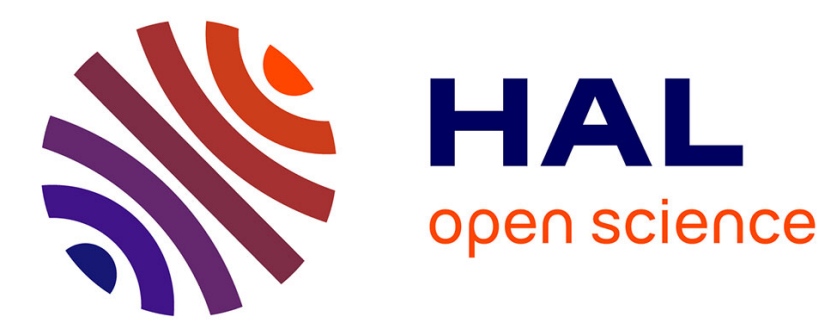

\title{
Zebiriosides A-L, oleanane saponins from the roots of Dendrobangia boliviana
}

\author{
Ilhem Zebiri, Mohamed Haddad, Laurent Duca, Dominique Harakat, Billy \\ Cabanillas, Lucie Paloque, Amandine Scandolera, Michel Sauvain, Elsa \\ Rengifo, Laurence Voutquenne-Nazabadioko
}

\section{To cite this version:}

Ilhem Zebiri, Mohamed Haddad, Laurent Duca, Dominique Harakat, Billy Cabanillas, et al.. Zebiriosides A-L, oleanane saponins from the roots of Dendrobangia boliviana. Phytochemistry, 2016, 130, pp.262-272. 10.1016/j.phytochem.2016.06.006 . hal-01937592

\section{HAL Id: hal-01937592 https://hal.science/hal-01937592}

Submitted on 22 Sep 2021

HAL is a multi-disciplinary open access archive for the deposit and dissemination of scientific research documents, whether they are published or not. The documents may come from teaching and research institutions in France or abroad, or from public or private research centers.
L'archive ouverte pluridisciplinaire HAL, est destinée au dépôt et à la diffusion de documents scientifiques de niveau recherche, publiés ou non, émanant des établissements d'enseignement et de recherche français ou étrangers, des laboratoires publics ou privés. 


\section{Graphical abstract}

Zebiriosides A-L, oleanane saponins from the roots of

\section{Dendrobangia boliviana}

Ilhem Zebiri*, Mohamed Haddad, Laurent Duca, Dominique

Harakat, Billy Cabanillas, Lucie Paloque, Amandine Scandolera, Michel Sauvain, Elsa Rengifo, Laurence Voutquenne-

Nazabadioko.

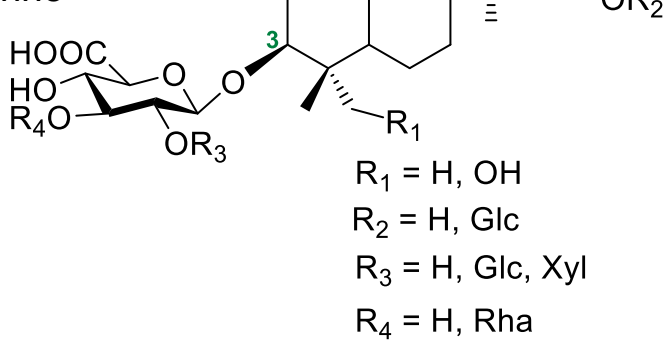

Twelve new glycosides of phytolaccinic acid or serjanic acid were isolated from $\mathrm{D}$. boliviana roots and their biological activities were evaluated. 


\title{
Zebiriosides A-L, oleanane saponins from the roots of Dendrobangia boliviana
}

\author{
Ilhem Zebiri ${ }^{\star, a}$, Mohamed Haddad ${ }^{\mathrm{b}}$, Laurent Ducac ${ }^{\mathrm{c}}$, Dominique Harakat ${ }^{\mathrm{a}}$, Billy \\ Cabanillas $^{d}$, Lucie Paloque ${ }^{e}, f$, Amandine Scandolera ${ }^{g}$, Michel Sauvain ${ }^{b}$, Elsa \\ Rengifo $^{d}$, and Laurence Voutquenne-Nazabadioko ${ }^{a}$.
}

aInstitut de Chimie Moléculaire de Reims UMR 7312 CNRS, Université de Reims ChampagneArdenne, BP 1039, 51687 REIMS Cedex, France.

'UMR 152 Pharma Dev, Université de Toulouse, IRD, UPS, France.

'Unité Matrice Extracellulaire et Dynamique Cellulaire (MEDyC), UMR CNRS 7369, Université de Reims Champagne-Ardenne, BP 1039, 51687 REIMS Cedex, France.

¿Instituto de Investigación de la Amazonía Peruana (IIAP), Iquitos-Quistococha, Perú ${ }^{\text {e}}$ CNRS, LCC (Laboratoire de Chimie de Coordination) UPR8241, 205 route de Narbonne, BP 44099, F-31077 Toulouse Cedex 4, France

'Université de Toulouse, UPS, INPT, F-31077 Toulouse Cedex 4, France

g Givandan ACl, Soliance, Route de Bazancourt, Pomacle, France

\section{*Corresponding Author}

E-mail: lila_z@hotmail.com. Tel : 0033632713779 


\section{Abstract}

Twelve oleanane saponins, zebiriosides A-L, were isolated from the roots of Dendrobangia boliviana Rusby, together with two known saponins, talunùmoside I and 3-O- $\beta$-Dglucuronopyranosyl serjanic acid. These saponins are glycosides of serjanic or phytolaccinic acid. Their structures were established on the basis of their spectral data, mainly HRTOFESIMS, 1D-NMR $\left({ }^{1} \mathrm{H},{ }^{13} \mathrm{C}\right.$, DEPT) and 2D-NMR $\left({ }^{1} \mathrm{H}-{ }^{1} \mathrm{H}\right.$ COSY, TOCSY, HSQC, HMBC, and ROESY), and by comparison with literature data. These compounds were evaluated for their cytotoxic, antileishmanial and hemolytic activities. No antileishmanial or hemolytic activities were revealed but zebirioside $\mathrm{C}$ and zebirioside I showed cytotoxicity against fibroblasts with $\mathrm{IC}_{50}$ of 6.4 and $5.6 \mu \mathrm{M}$, respectively.

Keywords: Dendrobangia boliviana, Cardiopteridaceae, Triterpenoid saponins, Cytotoxic activity 


\section{Introduction}

Firstly classified in the family of Icacinaceae by Rusby in 1896, the genus Dendrobangia was moved in 2001 from Icacinaceae to Cardiopteridaceae by Kârehed who conducted a cladistic study based on morphological and biological characters (DNA sequences analysis), and divided the Icacinaceae "sensu lato" in four families and three order: Icacinaceae " sensu stricto » (Garryales), Cardiopteridaceae and Stemonuraceae (Aquifoliales) and Pennantiaceae (Apiales)(Karehed, 2001). The Cardiopteridaceae is composed of 43 species in 6 genera and are located in tropical zones. The genus Dendrobangia is composed of three species: $D$. multinerva Ducke, $D$. tenuis Ducke and $D$. boliviana Rusby, large trees growing in the tropical area. No phytochemical studies on this genus have been reported so far. Dendrobangia boliviana Rusby is a tree of 5 to $30 \mathrm{~m}$ high and $50 \mathrm{~cm}$ in diameter widely distributed in the Neotropical region of Costa Rica and Panama, Brazil and Bolivia. It grows in mountain forests and rarely in floodplain forests between 100 and $1200 \mathrm{~m}$ altitude, and tolerates a wide range of soils. In Colombia, the community of the region Hibito consumes the fine fruits like dried fruits. The wood of this tree is used for its strength in construction, furniture, sporting goods, tool handles, interior coverings(De Stefano, 2007). In order to discover previously undescribed secondary metabolites of biological importance from Peru's Amazon rainforest, we investigated the roots of $D$. boliviana. This paper deals with the isolation and structure elucidation of twelve previously undescribed oleanane saponins (1-12) and two known compounds. The characterization of these 14 compounds from the roots of $D$. boliviana, studied for the first time in a chemical and biological point of view, leads us to explore the cytotoxic, antileishmanial and hemolytic activities of our different molecules.

\section{Results and discussion}

The hydromethanolic extract of the roots of $D$. boliviana was purified by multiple chromatographic steps over silicagel and reversed phase $C_{18}$ and finally by semi-preparative HPLC, yielding twelve previously undescribed saponins, zebiriosides $A$ to $L$ (1-12), together with two known compounds, 3-O- $\beta$-D-glucuronopyranosyl serjanic acid (13) (Jayasinghe et al., 1998) and talunùmoside I (14) (Kohda et al., 1992) (Figure 1). Their structures were elucidated by a detailed analysis of their spectral data including 2D NMR experiments (COSY, TOCSY, HSQCJ-modulate, HMBC, and ROESY) and mass spectrometry. Acid hydrolysis of the crude saponin precipitate afforded four sugar units in the aqueous layer, identified by analysis on a chiral column as D-glucuronic acid (GlcA), D-glucose (Glc), D-xylose (Xyl) and L-rhamnose (Rha).

Compound 1 was obtained as a white powder. The HRESIMS (positive ion mode) exhibited a pseudomolecular ion peaks at $m / z 845.4290\left([\mathrm{M}+\mathrm{Na}]^{+}\right.$, calcd for $\left.\mathrm{C}_{43} \mathrm{H}_{66} \mathrm{O}_{15} \mathrm{Na}, 845.4299\right)$ 
indicating a molecular formula of $\mathrm{C}_{43} \mathrm{H}_{66} \mathrm{O}_{15}$. The ${ }^{1} \mathrm{H}$ NMR spectra of the aglycone part indicated the presence of six tertiary methyl groups at $\delta_{\mathrm{H}} 0.82$ (s, Me-26), 0.87 (s, Me-24), 0.97 (s, Me-25), 1.07 (s, Me-23), 1.16 (s, Me-29), and 1.19 (s, Me-27), one olefinic proton at $\delta_{H} 5.32(J=3.4 \mathrm{~Hz}, \mathrm{H}-12)$, one oxygenated methine protons at $\delta_{H} 3.19$ (dd, J=11.8-4.5 Hz, H3 ) and the deshielded proton $\mathrm{H}-18$ at $\delta_{H} 2.71(\mathrm{dd}, J=13.8-4.5 \mathrm{~Hz}$ ), in the carbonyl anisotropy cone of C-28. A methoxy group was also observed at $\delta_{H} 3.72$. Its ${ }^{13} \mathrm{C} N M R$ and HSQC spectra exhibited signals for six methyls groups at $\delta_{\mathrm{C}} 15.9$ (C-25), 17.0 (C-24), 17.7 (C-26), 26.4 (C-27), 28.5 (C-23), and 28.7 (C-29), one hydroxy group at C-3 ( $\left.\delta_{C} 91.2\right)$ and two olefinic carbons at $\delta_{C} 124.3$ (C-12) and 144.7 (C-13), characteristic of an oleane-12-ene skeleton (Jayasinghe et al., 1998; Kohda et al., 1992; Mahato and Kundu, 1994); together with two carbonyl groups at $\delta_{C} 178.8$ and 181.3 and a methoxy group at $\delta_{C} 52.3$. The HMBC correlations observed between $\mathrm{H}-18$ and the C-28 carbonyl carbon (181.3 ppm) indicate a carboxylic group in C-28. The HMBC correlations between the carbonyl carbon at $\delta_{\mathrm{C}} 178.8$ with protons $H \beta-19\left(\delta_{H} 1.69\right), H \alpha-21\left(\delta_{H} 2.01\right), H-29\left(\delta_{H} 1.16\right)$ and methoxy group $\left(\delta_{H} 3.72\right)$ suggest an ester carbonyl at $\mathrm{C}-30$. The $3 \beta$ configuration of the hydroxyl group was confirmed from the ROESY experiment in which correlations were observed between $\mathrm{H}-3 \alpha, \mathrm{H}-5 \alpha$, and $\mathrm{H}-23 \alpha$. These data are consistent with serjanic acid or $3 \beta$-hydroxy-30-methylcarboxylate oleane-12-ene-28-oic acid (Montoya Pelaez et al., 2013). The deshielded nature of C-3 ( $\delta_{c}$ 91.2) suggested a monodesmosidic saponin with an osidic chain at this position.

The ${ }^{1} \mathrm{H}$ and ${ }^{13} \mathrm{C}$-NMR spectra revealed the presence of two sugar units with anomeric protons at $\delta_{\mathrm{H}} 5.19 \mathrm{ppm}(\mathrm{d}, J=1.7 \mathrm{~Hz})$ and $4.41 \mathrm{ppm}(\mathrm{d}, J=7.9 \mathrm{~Hz})$ and the corresponding carbons at $\delta_{\mathrm{C}} 102.8$, and 106.8 suggesting two osidic units (Agrawal, 1992). A methyl signal at $\delta_{H} 1.25(\mathrm{~d}, J=6.2 \mathrm{~Hz})$, and $\delta_{\mathrm{C}} 17.8$ indicated a 6-desoxy-hexose and a carbonyl carbon at $\delta_{C} 172.5$ indicated a hexosuronic moiety. Analysis of COSY and ROESY correlations allowed us to assign complete spin systems of a $\beta$-D-glucuropyranose and a $\alpha$-L-rhamnopyranose (Bock and Pedersen, 1983 ) (Table 1). The carbons of each monosaccharide were attributed by analysis of HSQC spectra and indicated the presence of a terminal $\alpha$-L-rhamnopyranose, and a 3-substitued $\beta$-D-glucuronic acid $\left(\delta_{\mathrm{C}} 83.4\right)$ (Table 1). The linkage sites of the monosaccharide units were determined by analysis of $\mathrm{HMBC}$ spectrum. The HMBC correlations between the $\beta$-D-glucuropyranose anomeric proton $\mathrm{H}-1$ ' (GlcA-H-1') at $\delta_{\mathrm{H}} 4.41$ and the carbon $\mathrm{C}-3$ of the genin $\left(\delta_{C} 91.2\right)$ indicates the position of the sugar on the serjanic acid, and between the $\alpha$-L-rhamnopyranose anomeric proton $\mathrm{H}-1$ " (Rha- $\mathrm{H}-1$ ") at $\delta_{\mathrm{H}} 5.19$ and the $\beta$-D-glucuropyranose carbon C-3' ( $\left.\delta_{C} 83.4\right)$ (GlcA-C-3'). Consequently, the structure of saponin 1 , zebirioside $A$, was concluded to be 3-O- $\alpha$-L-rhamnopyranosyl-( $1 \rightarrow 3)-\beta$-Dglucuronopyranosyl serjanic acid (Figure 1). 
Compound 2, was obtained as a white powder. The positive HRESIMS spectra gave a pseudomolecular ion peaks at $\mathrm{m} / z$ 1007.4835 ([M+Na] $]^{+}$calcd for $\left.\mathrm{C}_{49} \mathrm{H}_{76} \mathrm{O}_{20} \mathrm{Na}, 1007.4828\right)$ corresponding to the molecular formula $\mathrm{C}_{49} \mathrm{H}_{76} \mathrm{O}_{20}$. The ${ }^{1} \mathrm{H}$ - and ${ }^{13} \mathrm{C}-\mathrm{NMR}$ spectra were very similar to those of compound 1, except for the presence of a supplementary hexose unit and an ester glycosidic linkage at C-28 ( $\left.\delta_{c} 177.6\right)$ of serjanic acid. From the anomeric proton at $\delta_{H} 5.36(d, J=8.2 \mathrm{~Hz})$ and the corresponding anomeric carbon at $\delta_{C} 95.8$, a $\beta$-Dglucopyranose moiety was identify by analysis of COSY and HSQC spectra (Table 1) (Bock and Pedersen, 1983 ). The chemical shifts of C-3 ( $\left.\delta_{C} 91.2\right)$ and C-28 ( $\left.\delta_{C} 177.6\right)$ confirmed the attachment of the sugar units to the aglycone and showed that compound 2 was a bidesmosidic saponin. This was confirmed by the HMBC correlations between GlcA-H-1' $\left(\delta_{H}\right.$ 4.59)/C-3 ( $\left.\delta_{C} 91.2\right)$ and Glc $H-1$ '" ( $\left.\delta_{H} 5.36\right) / C-28$ ( $\left.\delta_{C} 177.6\right)$. Another HMBC correlation between Rha-H-1" ( $\left.\delta_{H} 5.19\right) / G l c A-C-3 '\left(\delta_{C} 78.3\right)$ revealed the sequencing in the disaccharide moiety. Thus, saponin $\mathbf{2}$, zebirioside $B$, was elucidated as the previously undescribed 3-O- $\alpha-$ L-rhamnopyranosyl-(1 $\rightarrow 3$ )- $\beta$-D-glucuronopyranosyl-28-O- $\beta$-D-glucopyranosyl serjanic acid (Figure 1).

Compound 3 was obtained as a white powder. The positive HRESIMS spectra gave a pseudomolecular ion peaks at $\mathrm{m} / z$ 1007.4832 ([M+Na $]^{+}$, calcd for $\mathrm{C}_{49} \mathrm{H}_{76} \mathrm{O}_{20} \mathrm{Na}, 1007.4828$ ) corresponding to the same molecular formula $\mathrm{C}_{49} \mathrm{H}_{76} \mathrm{O}_{20}$ as compound 2 and suggesting that these compounds were isomers. The ${ }^{1} \mathrm{H}$ - and ${ }^{13} \mathrm{C}-\mathrm{NMR}$ spectra were very similar to those of compound 2, except of the chemical shift of C-28 ( $\left.\delta_{C} 181.3\right)$ of serjanic acid suggesting a free carboxylic acid. Thus the glucopyranose was not linked with an ester linkage in compound 3. This was confirmed by the deshielding carbons $C-2^{\prime}\left(\delta_{C} 78.1\right)$ and $C-3^{\prime}\left(\delta_{C}\right.$ 86.0) of $\beta$-D-glucuropyranosyl moiety indicating that it is disubstituted on these positions (Table 1). The HMBC correlations between GlcA-C-3' $\left(\delta_{C} 86.0\right)$ and $\mathrm{H}-3$ of the aglycone, Rha-H-1"/GlcA-C-3', and Glc-H-1"'/ GlcA-C-2', confirmed a trisaccharide chain attached to position C-3 of serjanic acid. Thus, compound 3, zebirioside C, was identified as 3-O- $\alpha-L-$ rhamnopyranosyl-( $1 \rightarrow 3)$-[ $\beta$-D-glucopyranosyl-( $1 \rightarrow 2)]-\beta$-D-glucuronopyranosyl serjanic acid (Figure 1).

Compound 4 was obtained as a white powder and their positive HRESIMS spectra gave the molecular formula $\mathrm{C}_{49} \mathrm{H}_{76} \mathrm{O}_{20}$ by the pseudomolecular ion peaks at $m / z 977.4727\left([\mathrm{M}+\mathrm{Na}]^{+}\right.$, calcd for $\left.\mathrm{C}_{48} \mathrm{H}_{74} \mathrm{O}_{19} \mathrm{Na}, 977.4722\right)$. Comparison of the ${ }^{1} \mathrm{H}$ - and ${ }^{13} \mathrm{C}-\mathrm{NMR}$ spectra of compounds $\mathbf{3}$ and $\mathbf{4}$ showed three sugars linked to the hydroxyl in position 3 of serjanic acid and the absence of the glucopyranose unit replaced by a pentose unit in compound 4 . The anomeric proton $\mathrm{H}-1$ "' of the third sugar is at $\delta_{\mathrm{H}} 4.40$ and its anomeric carbon $\mathrm{C}-1$ "' at $\delta_{\mathrm{C}}$ to 104.8 (Table 1). The chemical shifts and coupling constants indicate a $\beta$-D-xylopyranose (Bock and Pedersen, 1983 ). The linkage was deduced by HMBC correlations between GlcA- 
$\mathrm{H}-1$ '/C-3, Rha-H-1"/GlcA-C-3', and Xyl-H-1"'/ GlcA-C-2'. Thus, compound 4, zebirioside D, was concluded to be 3-O- $\alpha$-L-rhamnopyranosyl-( $1 \rightarrow 3)$-[ $\beta$-D-xylopyranosyl-( $1 \rightarrow 2)]-\beta-D-$ glucuronopyranosyl serjanic acid (Figure 1).

Compound 5 was obtained as a white powder. Its molecular formula $\mathrm{C}_{54} \mathrm{H}_{84} \mathrm{O}_{24}$ was deduced from the pseudomolecular ion peaks at $m / z 1139.5260\left([\mathrm{M}+\mathrm{Na}]^{+}\right.$, calcd for $\mathrm{C}_{54} \mathrm{H}_{84} \mathrm{O}_{24} \mathrm{Na}$, 1139.5250) in the positive HRESIMS spectra indicating an additional hexose unit when compare to compound 4 . The ${ }^{1} \mathrm{H}$ - and ${ }^{13} \mathrm{C}-\mathrm{NMR}$ spectra were very similar to those of compound 4 with the same trisaccharide chain attached to C-3 of serjanic acid but this compound is glucosylated at position C-28 $\left(\delta_{C} 177.5\right)$ as in compound 2 (Table 1). This compound 5, Zebirioside E, was identified as 3-O- $\alpha$-L-rhamnopyranosyl-(1 $\rightarrow 3)$-[ $[\beta-D-$ xylopyranosyl-( $1 \rightarrow 2)$ ]- $\beta$-D-glucuronopyranosyl-28-O- $\beta$-D-glucopyranosyl serjanic acid (Figure 1).

Compounds 6 and 7 (Figure 1) were obtained as a white amorphous powder. The molecular formula $\mathrm{C}_{54} \mathrm{H}_{84} \mathrm{O}_{24}$ for 6 and $\mathrm{C}_{53} \mathrm{H}_{82} \mathrm{O}_{23}$ for 7 were determined separately for the both compounds from the pseudomolecular ion peak observed in positive HRESIMS at $\mathrm{m} / \mathrm{z}$ $1139.5242[\mathrm{M}+\mathrm{Na}]^{+}$for 6 and at $m / z 1109.5149[\mathrm{M}+\mathrm{Na}]^{+}$for 7 , indicating a supplementary pentose unit comparing to those of compounds 3 and 4 , respectively. The ${ }^{1} \mathrm{H}$ NMR and ${ }^{13} \mathrm{C}$ NMR spectra of $\mathbf{6}$ and $\mathbf{7}$ showed signals assignable to four sugars moieties. Analysis of COSY, TOCSY, HSQCJ-modulate, and HMBC experiments allowed us to identify three sugars moieties as in compounds $\mathbf{3}$ and $\mathbf{4}$, a $\beta$-D-glucuronopyranose substituted at positions C-2' by a $\beta$-D-glucopyranose in 6 (Table 1) or a $\beta$-D-xylopyranose in 7 (Table 2), and C-3' by a $\alpha$-L-rhamnopyranose. The supplementary sugar unit was identifying as a $\beta$-D-xylopyranose in both compounds 6 and 7. This sugar was attached to the $\alpha$-L-rhamnopyranose at C-3" as suggested by the deshielding signal of C-3" ( $\left.\delta_{C} 81.5\right)$ (Tables 1 and 2). The HMBC correlations in compound 6 [GlcA-H-1'/C-3, Rha-H1"/GlcA-C-3', Glc-H-1'"/ GlcA-C-2' and Xyl$\mathrm{H}-1^{\mathrm{IV}} /$ Rha-C-3"] allowed us to confirm the point of linkages of the sugars each other and on the aglycone. Thus, saponin 6 , zebirioside F, was identified as 3-O- $\beta$-D-xylopyranosyl-( $1 \rightarrow 3)$ $\alpha$-L-rhamnopyranosyl-( $1 \rightarrow 3)$-[ $\beta$-D-glucopyranosyl-( $1 \rightarrow 2)]$ - $\beta$-D-glucuronopyranosyl serjanic acid. The structure of compound 7 , zebirioside $G$, is also deduced from the HMBC correlations [GlcA-H-1'/C-3, Rha-H1"/GlcA-C-3', Xyl-H-1'"/GlcA-C-2' and Xyl-H-1'IV/Rha-C-3"] to 3-O- $\beta$-D-xylopyranosyl-(1 $\rightarrow 3)$ - $\alpha$-L-rhamnopyranosyl-( $1 \rightarrow 3)$-[ $\beta$-D-xylopyranosyl-( $1 \rightarrow 2)]-\beta-D-$ glucuronopyranosyl serjanic acid.

Compounds 8 and 9 (Figure 1) were obtained as a white powder. Their molecular formula $\mathrm{C}_{60} \mathrm{H}_{94} \mathrm{O}_{29}$ for 8 and $\mathrm{C}_{59} \mathrm{H}_{92} \mathrm{O}_{28}$ for $\mathbf{9}$ obtained in positive HRESIMS, indicates a supplementary hexose unit by comparing to those of compounds 6 and 7 . As in compounds 2 and $\mathbf{5}$, these compounds are bidesmoside saponins with a $\beta$-D-glucopyranose attached by 
an ester linkage to the C-28 of compounds 6 and 7, respectively (Table 2). Thus, their structures were established as 3-O- $\beta$-D-xylopyranosyl-( $1 \rightarrow 3)$ - $\alpha$-L-rhamnopyranosyl- $(1 \rightarrow 3)$-[ $[\beta$ D-glucopyranosyl-( $1 \rightarrow 2)$-] $\beta$-D-glucuronopyranosyl-28-O- $\beta$-D-glucopyranosyl serjanic acid (Zebirioside $H$ ) for saponin 8 and 3-O- $\beta$-D-xylopyranosyl-( $1 \rightarrow 3)$ - $\alpha$-L-rhamnopyranosyl- $(1 \rightarrow 3)$ $[\beta$-D-xylopyranosyl-( $1 \rightarrow 2)-] \beta-D-g l u c u r o n o p y r a n o s y l-28-O-\beta$-D-glucopyranosyl serjanic acid (Zebirioside I) for compound 9.

Compounds 10,11 and 12 (Figure 1) were obtained as white amorphous powders. Analysis of $1 \mathrm{D}\left({ }^{1} \mathrm{H},{ }^{13} \mathrm{C}\right)$ and $2 \mathrm{D}$ NMR spectra (COSY, HSQC, and HMBC) indicated that the aglycone was different. Five methyl groups instead of six were observed at $\delta_{\mathrm{H}} 0.60(\mathrm{H}-24), 0.70(\mathrm{H}-$ 26), $0.87(\mathrm{H}-25), 1.04(\mathrm{H}-29)$ and 1.09 (H-27) and $\delta_{\mathrm{C}} 13.4$ (C-24), 17.9 (C-26), 16.4 (C-25), 28.7 (C-29) and 26.4 (C-27), respectively. The singlet corresponding to the methyl at C-23 has disappeared and the $\mathrm{C}-24$ is shielded due to its environmental change. An additional methylene at $\delta_{\mathrm{H}} 3.51(\mathrm{~d}, J=11.5 \mathrm{~Hz})$ and $3.18(\mathrm{~d}, J=11.5 \mathrm{~Hz})$, and $\delta_{\mathrm{C}} 64.6 \mathrm{ppm}$ indicate the presence of an hydroxyl group on the C-23. This is confirmed by the HMBC correlations between $\mathrm{H}-24\left(\delta_{\mathrm{H}} 0.60\right)$ and the carbons $\mathrm{C}-4\left(\delta_{\mathrm{C}} 44.0\right), \mathrm{C}-5\left(\delta_{\mathrm{C}} 48.0\right), \mathrm{C}-3\left(\delta_{\mathrm{C}} 83.4\right)$ and C-23 $\left(\delta_{C} 64.6\right)$. Thus, the genin of these compounds is phytolaccinic acid (Johnson and Shimizu, 1974).

For compound 10, in addition to phytolaccinic acid, signals for two sugars units, a $\beta$-Dglucuronopyranose substituted at C-2' and an $\alpha$-L-rhamnopyranose were observed (Table 2 ). The HMBC correlations observed between GlcA-H-1'/C-3 ( $\left.\delta_{c} 83.4\right)$ and Rha-H-1"/GlcA-C-3' ( $\left.\delta_{c} 83.4\right)$ confirm the glycosidic linkage and allow us to establish the structure of compound 10 , zebirioside J, as 3-O- $\alpha$-L-rhamnopyranosyl-( $1 \rightarrow 3)$ - $\beta$-D-glucuronopyranosyl-phytolaccinic acid.

Compound $\mathbf{1 1}$ is the bidesmoside of compound $\mathbf{1 0}$ glucosylated in C-28. It is identified as 3O- $\alpha$-L-rhamnopyranosyl-( $1 \rightarrow 3)$ - $\beta$-D-glucuronopyranosyl-28-O- $\beta$-D-glucopyranosyl phytolaccinic acid (zebirioside $\mathrm{K}$ ).

For compound 12 signals for three sugars units, a $\beta$-D-glucuronopyranose substituted at C-3' ( $\delta_{C}$ 83.1), a $\alpha$-L-rhamnopyranose substituted at C-3" ( $\left.\delta_{C} 82.3\right)$ and a $\beta$-D-xylopyranose were observed (Table 2). The HMBC correlations between GlcA-H-1'/C-3, Rha-H1"/GlcA-C-3', and $\mathrm{Xyl}-\mathrm{H}-1$ '"'/Rha-C-3" indicated the site of linkages. Thus, compound 12, zebirioside $\mathrm{L}$, was identified as 3-O- $\beta$-D-xylopyranosyl-( $1 \rightarrow 3)$ - $\alpha$-L-rhamnopyranosyl-( $1 \rightarrow 3)-\beta-D-$ glucuronopyranosyl phytolaccinic acid.

The characterization of the twelve previously undescribed compounds, together with two known saponins from the roots of Dendrobangia boliviana, leads us to explore the cytotoxic, antileishmanial and hemolytic activities of our different molecules. 
The hemolytic activity is considered to be a typical characteristic of saponins because of their detergent-like properties, caused by a rapid cell lysis interacting with membrane cholesterol, although, some saponins show only weak or no hemolytic effect. The hemolytic activity of the isolated saponins was assessed using the method previously described (Chwalek et al., 2006). No hemolytic activity was observed for compounds 1-14.

When comparing the cytotoxic activity and the hemolytic activity of different triterpene bidesmoside saponins (Bader et al., 1996; Chwalek et al., 2006), the conclusion was that these two activities were generally directly correlated. In this work, the cytotoxicity on fibroblasts of compounds 1-14 was evaluated at a concentration of $10 \mu \mathrm{g} / \mathrm{mL}$ (Table 3). Zebirioside C (3) (monodesmosidic saponin) and I (9) (bidesmosidic saponin) were not hemolytic in the range of concentration tested whereas these compounds were found to be cytotoxic on fibrobasts ( $\mathrm{IC}_{50}$ of 5.6 and $6.4 \mu \mathrm{M}$, respectively). These data suggest that another mechanism than permeabilization formation is responsible of cell cytotoxicity. It is also conceivable that considering the different plasma membrane composition between these two cell types, membrane penetration of saponins could be different leading to different biological effect. Indeed, saponins possess detergent-like properties, they can also increase the permeability of cell membranes without destroying them. They could affect the interaction with trans-membrane proteins or with cytoskeleton proteins of cell membrane that could lead to different biological effects considering the specific plasma membrane composition of different cell types. In the case of cytotoxicity, saponins activity could results from membrane alteration and/or apoptosis which is induced by the condensation of chromatin and DNA fragmentation at the nuclear level (Chwalek et al., 2006). It is consequently possible that such a process is induced in fibroblasts. To confirm this hypothesis and to check the action of saponins $\mathbf{3}$ and $\mathbf{9}$, biological tests such as annexin V/propidium iodide stainings, analysis of chromatin condensation and analysis of apoptosis specific cell signalling pathways could be of interest.

In addition, the evaluation of the antileishmanial activity of these saponins on promastigotes of Leishmania infantum gave no activity.

\section{Conclusions}

Phytochemical study of the roots of Dendrobangia boliviana, a Peruvian plant used mainly for the robustness of its wood, led to the isolation of twelve previously undescribed saponins, zebirioside $A$ to $L$ (1-12), and two known saponins (13-14), which are glycosides of serjanic or phytolaccinic acid. Their chemical structures were determined by analyzing $1 \mathrm{D}$ and $2 \mathrm{D}$ NMR and MS data. This is the first report of the constituents of Dendrobangia species. These saponins were tested for their cytotoxic, leishmanicidal and hemolytic activities. No 
antileishmanial or hemolytic activity was revealed and only zebirioside C (3) and I (9) have shown cytotoxicity against fibroblasts $\left(\mathrm{IC}_{50} 5.6\right.$ and $6.4 \mu \mathrm{M}$, respectively). This activity is interesting because these saponins have demonstrated no hemolytic activity, suggesting a specific action mode, depending on the cell type. This phytochemical investigation helps us to extend the knowledge about the constituents of the unstudied Dendrobangia genus.

\section{Experimental}

\subsection{General experimental procedures}

Optical rotations were measured in $\mathrm{MeOH}$ with a Perkin-Elmer 241 polarimeter. ${ }^{1} \mathrm{H}$ and ${ }^{13} \mathrm{C}$ NMR spectra were recorded in $\mathrm{CD}_{3} \mathrm{OD}$ on a Bruker Avance III-600 spectrometer equipped with a cryo plateform $\left({ }^{1} \mathrm{H}\right.$ at $600 \mathrm{MHz}$ and ${ }^{13} \mathrm{C}$ at $\left.151 \mathrm{MHz}\right) .{ }^{2} \mathrm{D}$ NMR experiments were performed using standard Bruker microprograms (TopSpin version 3.2 software). HR-ESIMS and ESI-MS experiments were performed using a Micromass Q-TOF micro-instrument (Manchester, UK). The samples were introduced by direct infusion in a solution of $\mathrm{MeOH}$ at a rate of $5 \mu \mathrm{M} / \mathrm{min}$. TLC were carried out on precoated silica gel $60 \mathrm{~F}_{254}$ (Merck), with $\mathrm{CHCl}_{3} / \mathrm{MeOH} / \mathrm{H}_{2} \mathrm{O}(70 / 30 / 5)$, and spots were visualizes by heating after spraying with $50 \%$ $\mathrm{H}_{2} \mathrm{SO}_{4}$.

Vacuum liquid chromatography was carried out on Lichroprep RP-C ${ }_{18}$ (40-63 $\mu \mathrm{m}$, Merck). High Performance Flash Chromatography (HPFC) was realized on Grace $\AA^{8}$ Reveleris System using Grace ${ }^{\circledR}$ cartridges (Silica gel or RP- $\mathrm{C}_{18}$ ) and a flow rate of $18 \mathrm{~mL} / \mathrm{min}$. The chromatograms were monitored at 205 and $210 \mathrm{~nm}$.

Analytical HPLC was performed on a Dionex apparatus equipped with a WPS-3000 automated sample injector, a TTC-3000 column oven, a LPG-3400SD pump, a diode array detector UVD-340U and the Chromeleon® software. Prepacked $\mathrm{C}_{18}-2$ reversed phase columns $4.6 \times 250 \mathrm{~mm}, 5 \mu \mathrm{m}, 100 \mathrm{~A}^{\circ}$ (Interchim or Phenomenex) were used with a binary gradient elution $\left(\mathrm{H}_{2} \mathrm{O}-\mathrm{TFA} 0.025 \% / \mathrm{MeCN}\right)$ and a flow rate of $1 \mathrm{~mL} / \mathrm{min}$. The chromatograms were monitored at 205 and $210 \mathrm{~nm}$.

The semi-preparative HPLC was performed on a Dionex apparatus equipped with an ASI100 automated sampler injector, a STH 585 column oven, a LPG-3400A pump, a diode array detector UVD-340U and the Chromeleon ${ }^{\circledR}$ software. Prepacked $\mathrm{C}_{18}$ reversed phase columns Luna $5 \mathrm{u} \mathrm{C}_{18}, 250 \times 10 \mathrm{~mm}, 5 \mu \mathrm{m}, 100 \mathrm{~A}^{\circ}$ (Phenomenex) or Luna $5 \mathrm{u}, \mathrm{C}_{18}, 250 \times 15 \mathrm{~mm}, 5$ $\mu \mathrm{m}, 100 \mathrm{~A}^{\circ}$ (Interchim) were used with a binary gradient elution $\left(\mathrm{H}_{2} \mathrm{O}-\mathrm{TFA} 0.025 \% / \mathrm{MeCN}\right)$ and a flow rate of $5 \mathrm{~mL} / \mathrm{min}$. The chromatograms were monitored at 205 and $210 \mathrm{~nm}$. The chiral chromatography was performed on a Waters apparatus equipped with an automated sampler injector 717 plus, a CO-965 column oven, a system controller 600E, a 60F extended pump diode array detector Waters-996 and a refractometer RI Waters-410 and 
the Empower® software. Prepacked column Chiralpack IC (Phenomenex) 4.6 x 250 mm, 5 $\mu \mathrm{m}$ was used with an isocratic solvent (Hexane/EtOH/TFA 50/50/0.1) and a flow rate of 0.5 $\mathrm{mL} / \mathrm{min}$.

\subsection{Plant material}

Dendrobangia boliviana (roots) were collected and identified in lquitos, Loreto district, Peru by C. Amasifusen, E. Rengifo and M. Haddad, in September 2011. A voucher specimen (No. CA3240) was carried out and deposed at the national Herbarium of the National University San Marcos in Lima, Peru (UNMSM).

\subsection{Extraction and isolation of compounds 1-14}

The powdered dried roots of $D$. boliviana $\left(150 \mathrm{~g}\right.$ ) were extracted by maceration in $\mathrm{MeOH} / \mathrm{H}_{2} \mathrm{O}$ $(8 / 2 \mathrm{v} / \mathrm{v}, 1.5 \mathrm{~L})$ at room temperature for $24 \mathrm{~h}$. After filtration and evaporation to dryness under reduced pressure, the crude $\mathrm{MeOH}$ extract $(18.6 \mathrm{~g}$ ) was dissolved in $\mathrm{MeOH}(100 \mathrm{~mL})$ and precipitated into acetone $(1500 \mathrm{~mL})$. After filtration the saponin precipitate $(\mathrm{DBP})$ is dried up $(11.4 \mathrm{~g})$ under vacuum over $\mathrm{KOH}$. A part $(3.5 \mathrm{~g})$ of the saponin rich precipitate were solubilized in $\mathrm{H}_{2} \mathrm{O}$ and passed through an IRN77 $\left(\mathrm{H}^{+}\right)$Amberlite resin column (activation with $\mathrm{HCl} / \mathrm{H}_{2} \mathrm{O} 30 / 60$ and elution with $\mathrm{H}_{2} \mathrm{O} 100 \%$ ) to give a protonated saponins fraction. This saponin mixture $(2.7 \mathrm{~g})$ was fractionated by vacuum liquid chromatography on RP-18 eluted successively with $\mathrm{MeOH} / \mathrm{H}_{2} \mathrm{O} 2 / 8,4 / 6,6 / 4$ and $100 \% \mathrm{MeOH}$ (each $600 \mathrm{~mL}$ ) to give nine fractions (DB-A to DB-I). The fraction DB-E (438 mg) was fractionated by High Performance Flash Chromatography (HPFC) on silicagel ( $4 \mathrm{~g}$ cartridge) using a binary gradient of $\mathrm{CHCl}_{3} / \mathrm{MeOH}$ (10/0 to 6/4 for $10 \mathrm{~min}, 6 / 4$ for $20 \mathrm{~min}$ and 6/4 to 0/10 for $17 \mathrm{~min}$ ) to give 6 fractions (DB-E1 to DB-E6). The fraction DB-E4 $(245 \mathrm{mg})$ was fractionated in the same manner as DB-E to give 8 fractions DB-E4a to DB-E4H. Fractions DB-E4d (18 mg), DB-E4f (69 mg) and DB-E4G (30 mg) were purified by semi-preparative HPLC with an isocratic mixture of $\mathrm{ACN} / \mathrm{H}_{2} \mathrm{O}-\mathrm{TFA} 0.025 \%$ (35/65) for $20 \mathrm{~min}$ to give compounds 13 ( $\mathrm{Rt}=5.05 \mathrm{~min}$, $54 \mathrm{mg}$,) and 10 (Rt = $5.6 \mathrm{~min}, 25 \mathrm{mg})$. Fraction DB-F (193 mg) was fractionated by HPFC on silica gel ( $4 \mathrm{~g}$ cartridge) with a binary gradient of $\mathrm{CHCl}_{3} / \mathrm{MeOH}(10 / 0$ to $0 / 10)$ for 30 min to give 9 fractions (DB-F1 to DB-F9). Fractions DB-F5 (9 mg) and DB-F6 (35 mg) were purified by semi-preparative HPLC in isocratic conditions (ACN/ $\mathrm{H}_{2} \mathrm{O}-\mathrm{TFA} 0.025 \%$ (45/55) for $20 \mathrm{~min}$ ) to afford compounds $8(\mathrm{Rt}=8.7 \mathrm{~min}, 14 \mathrm{mg})$ and $4(\mathrm{Rt}=7.4 \mathrm{~min}, 8 \mathrm{mg})$. The fraction BD-F7 (108 mg) was purified by semi-preparative HPLC using a gradient of $\mathrm{ACN} / \mathrm{H}_{2} \mathrm{O}-0.025 \%$ TFA (3/7 to $38 / 62$ for $30 \mathrm{~min}$ ) to give the compounds 10 ( $\mathrm{Rt}=5.4 \mathrm{~min}, 13 \mathrm{mg}), 11(\mathrm{Rt}=5.8 \mathrm{~min}, 4$ $\mathrm{mg}), 9(\mathrm{Rt}=5.9 \mathrm{~min}, 3 \mathrm{mg}), 4(\mathrm{Rt}=6.5 \mathrm{~min}, 15 \mathrm{mg}), 2(\mathrm{Rt}=7.7 \mathrm{~min}, 2 \mathrm{mg}), 14(\mathrm{Rt}=11.1$ $\mathrm{min}, 2 \mathrm{mg})$ and $12(\mathrm{Rt}=12.1 \mathrm{~min}, 14 \mathrm{mg})$. Fraction $\mathrm{DB}-\mathrm{G}(63 \mathrm{mg})$ was purified by semi- 
preparative HPLC using ACN/ $\mathrm{H}_{2} \mathrm{O}-\mathrm{TFA} 0.025 \%$ ( $1 / 9$ to $4 / 6$ for $5 \mathrm{~min}$ and $4 / 6$ for $15 \mathrm{~min}$ ) to give compounds $4(R t=8.4 \mathrm{~min}, 11 \mathrm{mg}), 2(R \mathrm{t}=8.8 \mathrm{~min}, 3 \mathrm{mg}), 12(R \mathrm{t}=11.4 \mathrm{~min}, 7 \mathrm{mg})$ and $7(\mathrm{Rt}=12.1 \mathrm{~min}, 5 \mathrm{mg})$. Fraction DB-H (197 mg) was fractionated by HPFC on silica gel (4 g cartridge) using $\mathrm{CHCl}_{3} / \mathrm{MeOH}$ (1/9 to 6/4 for $15 \mathrm{~min}, 6 / 4$ for $10 \mathrm{~min}$ and 6/4 to 0/10 for 10 $\mathrm{min}$ ) to give 9 fractions (DB-H1 to DB-H9). Fractions DB-H5 (15 mg) and DB-H6 (25 mg) were purified by semi-preparative HPLC with a gradient of $\mathrm{ACN} / \mathrm{H}_{2} \mathrm{O}-0.025 \%$ TFA (45/55 to $5 / 5)$ for $15 \mathrm{~min}$ to give compounds $3(\mathrm{Rt}=9.9 \mathrm{~min}, 13 \mathrm{mg})$ and $\mathbf{1}(\mathrm{Rt}=12.3 \mathrm{~min}, 4 \mathrm{mg})$. Fraction DB-H7 (50 mg) was purified by semi-preparative HPLC using a gradient of $\mathrm{ACN} / \mathrm{H}_{2} \mathrm{O}-0.025 \%$ TFA (4/6 to $\left.45 / 55\right)$ for $30 \mathrm{~min}$ to give compounds 7 ( $\mathrm{Rt}=8.4 \mathrm{~min}, 13 \mathrm{mg}$ ), $5(\mathrm{Rt}=8.8 \mathrm{~min}, 6 \mathrm{mg}), 8(\mathrm{Rt}=9.3 \mathrm{~min}, 7 \mathrm{mg}), 6(\mathrm{Rt}=98 \mathrm{~min}, 7 \mathrm{mg})$ and $3(\mathrm{Rt}=14.4 \mathrm{~min}$, $11 \mathrm{mg})$.

\subsection{Acid hydrolysis and identification of sugars units}

Saponins precipitate $(1.08 \mathrm{~g})$ was refluxed with $25 \mathrm{~mL}$ of $2 \mathrm{M}$ TFA for $4 \mathrm{~h}$. After extraction with EtOAc $(3 \times 30 \mathrm{~mL})$, the aqueous layer was neutralized to $\mathrm{pH} 6$ with $50 \mathrm{mM} \mathrm{KOH}$ and freezedried to provide the monosaccharide residue. The sugars profile was determined by comparison with authentic samples on TLC in MEtK/iso-Pro/ $/ \mathrm{Ac}_{2} \mathrm{O} / \mathrm{H}_{2} \mathrm{O}(20 / 10 / 7 / 6$, v/v). Detection was performed with $\alpha$-naphthol. The identification of sugars was determined by HPLC on an analytical chiral column Chiralpack® ICA (5 $\mu \mathrm{m}, 4.6 \times 250 \mathrm{~mm})$ eluted with an isocratic mixture of Hexane/EtOH/TFA (50/50/0.1, v/v) at a flow rate of $0.5 \mathrm{~mL} / \mathrm{min}$ and 35 ${ }^{\circ} \mathrm{C}$. Chromatograms were monitored by a refractive index detector RI-410 (Waters) and retention times of the sugars were compared to standard sugars (L-xylose, D-xylose, Lglucose, D-glucose, L-rhamnose and D-glucuronic acid).

4.5. Zebirioside $A$, 3-O- $\alpha$-L-rhamnopyranosyl-(1 $\rightarrow 3)-\beta-D-g l$ lucuronopyranosyl serjanic acid (1): White powder; $[\alpha]_{D^{20}}+14.3^{\circ}(c 0.87, \mathrm{MeOH}) ;{ }^{1} \mathrm{H} \mathrm{NMR}\left(600 \mathrm{MHz}\right.$, Methanol- $\left.d_{4}\right)$ of the aglycon: $\delta_{H} 5.32(1 \mathrm{H}, \mathrm{t}, J=3.4 \mathrm{~Hz}, \mathrm{H}-12), 4.41(1 \mathrm{H}, \mathrm{d}, J=7.9 \mathrm{~Hz}, \mathrm{H}-1$ '), $3.72(3 \mathrm{H}, \mathrm{s}, \mathrm{H}-31)$, $3.19(1 \mathrm{H}, \mathrm{dd}, J=11.8,4.5 \mathrm{~Hz}, \mathrm{H}-3), 2.71(1 \mathrm{H}, \mathrm{dd}, J=13.8,4.5 \mathrm{~Hz}, \mathrm{H}-18), 2.03(1 \mathrm{H}, \mathrm{td}, J=$ 13.6, 3.5 Hz , Ha-16 ), 2.01 (1H, m, Ha-21), $1.96(1 \mathrm{H}, \mathrm{m}, \mathrm{Ha}-19), 1.93$ (2H, dd, J = 9.3, 3.6 $\mathrm{Hz}, \mathrm{H}-11), 1.87(1 \mathrm{H}, \mathrm{dd}, J=13.5,4.5 \mathrm{~Hz}, \mathrm{Ha}-2), 1.78(1 \mathrm{H}, \mathrm{td}, J=13.6,4.3 \mathrm{~Hz}, \mathrm{Ha}-15), 1.70$

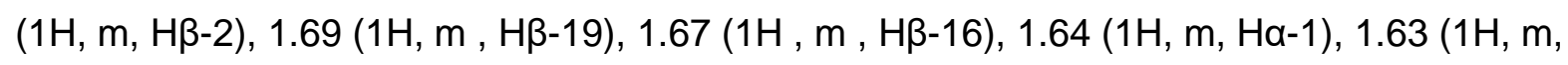
$\mathrm{H}-22), 1.62(1 \mathrm{H}, \mathrm{m}, \mathrm{H}-9), 1.58(1 \mathrm{H}, \mathrm{m}, \mathrm{Ha}-6), 1.54(1 \mathrm{H}, \mathrm{td}, J=12.4,4.1 \mathrm{~Hz}, \mathrm{Ha}-7), 1.44$

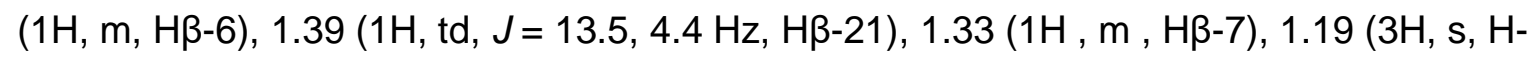
27), $1.16(3 \mathrm{H}, \mathrm{s}, \mathrm{H}-29), 1.12(1 \mathrm{H}, \mathrm{dt}, J=13.6,3.6 \mathrm{~Hz}, \mathrm{H} \beta-15), 1.07(3 \mathrm{H}, \mathrm{s}, \mathrm{H}-23), 1.01(1 \mathrm{H}$, $\mathrm{td}, J=13.3,3.6 \mathrm{~Hz}, \mathrm{H} \beta-1), 0.97$ (3H, s, H-25), 0.82 (4H, s, H-26, H-5), 0.87 (3H, s, H-24); ${ }^{13} \mathrm{C} \mathrm{NMR}\left(151 \mathrm{MHz}, \mathrm{CD}_{3} \mathrm{OD}\right)$ of the aglycon: $\delta \mathrm{c} 181.3(\mathrm{COOH}, \mathrm{C}-28), 178.8\left(\mathrm{COOCH}_{3}, \mathrm{C}-\right.$ 
30), 144.7 ( $\mathrm{HC}=\mathrm{C}, \mathrm{C}-13), 124.3$ ( $\mathrm{HC}=\mathrm{C}, \mathrm{C}-12), 91.2$ ( $\mathrm{CH}-\mathrm{O}, \mathrm{C}-3), 57.0(\mathrm{CH}, \mathrm{C}-5), 52.3$ $\left(\mathrm{COOCH}_{3}, \mathrm{C}-31\right), 49.0$ (CH, C-9), 47.0 (C, C-17), 45.0 (C, C-20), $44.0(\mathrm{CH}, \mathrm{C}-18), 43.4\left(\mathrm{CH}_{2}\right.$, C-19), 42.8 (C, C-14), 40.5 (C, C-8), 40.2 (C, C-4), $39.7\left(\mathrm{CH}_{2}, \mathrm{C}-1\right), 37.9$ (C, C-10), 35.0 $\left(\mathrm{CH}_{2}, \mathrm{C}-22\right), 34.0\left(\mathrm{CH}_{2}, \mathrm{C}-7\right), 31.3\left(\mathrm{CH}_{2}, \mathrm{C}-21\right), 28.9\left(\mathrm{CH}_{2}, \mathrm{C}-15\right), 28.7\left(\mathrm{CH}_{3}, \mathrm{C}-29\right), 28.5$ $\left(\mathrm{CH}_{3}, \mathrm{C}-23\right), 27.0\left(\mathrm{CH}_{2}, \mathrm{C}-2\right), 26.4\left(\mathrm{CH}_{3}, \mathrm{C}-27\right), 24.5\left(\mathrm{CH}_{2}, \mathrm{C}-11\right), 24.2\left(\mathrm{CH}_{3}, \mathrm{C}-16\right), 19.3$ $\left(\mathrm{CH}_{2}, \mathrm{C}-6\right), 17.7\left(\mathrm{CH}_{3}, \mathrm{C}-26\right), 17.0\left(\mathrm{CH}_{3}, \mathrm{C}-24\right), 15.9\left(\mathrm{CH}_{3}, \mathrm{C}-25\right) ;{ }^{1} \mathrm{H}$ and ${ }^{13} \mathrm{C}$ NMR of the glycosidic part, see Table 1; HRESIMS (positive-ion mode) $\mathrm{m} / \mathrm{z} 845.4290[\mathrm{M}+\mathrm{Na}]^{+}$ (calculated for $\mathrm{C}_{43} \mathrm{H}_{66} \mathrm{O}_{15} \mathrm{Na}$, 845.4299).

4.6. Zebirioside $B$, 3-O- $\alpha$-L-rhamnopyranosyl-(1 $\rightarrow 3)-\beta-D-g l$ lucuronopyranosyl-28-O- $\beta-D-$ glucopyranosyl serjanic acid (2): White powder; $[\alpha]_{D^{20}}+7.0^{\circ}(c 0.44, \mathrm{MeOH}) ;{ }^{1} \mathrm{H}$ NMR $(600$ $\mathrm{MHz}$, Methanol- $\left.d_{4}\right)$ of the aglycon: $\delta_{\mathrm{H}} 5.33(1 \mathrm{H}, \mathrm{t}, J=3.6 \mathrm{~Hz}, \mathrm{H}-12), 3.72(3 \mathrm{H}, \mathrm{s}, \mathrm{H}-31), 3.19$ $(1 \mathrm{H}, \mathrm{dd}, J=11.5,4.3 \mathrm{~Hz}, \mathrm{H}-3), 2.72(1 \mathrm{H}, \mathrm{dd}, J=13.7,4.0 \mathrm{~Hz}, \mathrm{H}-18), 2.08(1 \mathrm{H}, \mathrm{td}, J=15.0$, $3.8 \mathrm{~Hz}, \mathrm{Ha}-16$ ), 2.02 (1H, m, Ha-21), 1.97 (1H, ddd, J=13.7, 4.4, 2.6 Hz, Ha-19), 1.93 (2H, $\mathrm{dd}, J=8.9,3.4 \mathrm{~Hz}, \mathrm{H}-11), 1.86(1 \mathrm{H}, \mathrm{dq}, J=13.5,4.3 \mathrm{~Hz}, \mathrm{Ha}-2), 1.80$ (2H, m, Ha-15, Hß-16), $1.74(1 \mathrm{H}, \mathrm{dt}, J=13.8,3.4 \mathrm{~Hz}, \mathrm{H \alpha}-22), 1.71(1 \mathrm{H}, \mathrm{t}, J=13.7 \mathrm{~Hz}, \mathrm{H \beta}-19), 1.70(1 \mathrm{H}, \mathrm{m}, \mathrm{H} \beta-2)$, $1.64(1 \mathrm{H}, \mathrm{dt}, J=13.4,3.5 \mathrm{~Hz}, \mathrm{Ha}-1), 1.61(1 \mathrm{H}, \mathrm{m}, \mathrm{H}-9), 1.56(2 \mathrm{H}, \mathrm{m}, \mathrm{H \beta}-22 / \mathrm{Ha}-6), 1.51(1 \mathrm{H}$, m, Ha-7), $1.41(1 \mathrm{H}, \mathrm{m}, \mathrm{H} \beta-6), 1.33(1 \mathrm{H}, \mathrm{m}, \mathrm{H} \beta-7), 1.40(1 \mathrm{H}, \mathrm{td}, J=9.9,3.3 \mathrm{~Hz}, \mathrm{H} \beta-21), 1.19$ (3H, s, H-27), $1.16(3 \mathrm{H}, \mathrm{s}, \mathrm{H}-29), 1.12(1 \mathrm{H}, \mathrm{dt}, J=14.5,3.4 \mathrm{~Hz}, \mathrm{H} \beta-15), 1.07$ (3H, s, H-23), $1.00(1 \mathrm{H}, \mathrm{m}, \mathrm{H} \beta-1), 0.97$ (3H, s, H-25), $0.86(3 \mathrm{H}, \mathrm{s}, \mathrm{H}-5 / \mathrm{H}-24), 0.80(3 \mathrm{H}, \mathrm{s}, \mathrm{H}-26) ;{ }^{13} \mathrm{C} \mathrm{NMR}$ (151 MHz, CD $\left.{ }_{3} \mathrm{OD}\right)$ of the aglycon: $\delta_{\mathrm{C}} 178.8\left(\mathrm{COOCH}_{3}, \mathrm{C}-30\right), 177.6$ (COOR, C-28), 144.4 $(\mathrm{HC}=\mathrm{C}, \mathrm{C}-13), 124.4(\mathrm{HC}=\mathrm{C}, \mathrm{C}-12), 91.2(\mathrm{CH}-\mathrm{O}, \mathrm{C}-3), 52.4\left(\mathrm{COOCH}_{3}, \mathrm{C}-31\right), 49.0(\mathrm{CH}, \mathrm{C}-9)$, 57.0 (CH, C-5), 47.4 (C, C-17), 45.0 (C, C-20), 43.9 (CH, C-18), $43.3\left(\mathrm{CH}_{2}, \mathrm{C}-19\right), 42.8$ (C, C-14), 40.7 (C, C-8), 40.2 (C, C-4), $39.8\left(\mathrm{CH}_{2}, \mathrm{C}-1\right), 37.9$ (C, C-10), $34.4\left(\mathrm{CH}_{2}, \mathrm{C}-22\right), 34.0$ $\left(\mathrm{CH}_{2}, \mathrm{C}-7\right), 31.3\left(\mathrm{CH}_{2}, \mathrm{C}-21\right), 29.0\left(\mathrm{CH}_{2}, \mathrm{C}-15\right), 28.6\left(\mathrm{CH}_{3}, \mathrm{C}-29\right), 28.5\left(\mathrm{CH}_{3}, \mathrm{C}-23\right), 27.0$ $\left(\mathrm{CH}_{2}, \mathrm{C}-2\right), 26.2\left(\mathrm{CH}_{3}, \mathrm{C}-27\right), 24.5\left(\mathrm{CH}_{2}, \mathrm{C}-11\right), 24.1\left(\mathrm{CH}_{2}, \mathrm{C}-16\right), 19.3\left(\mathrm{CH}_{2}, \mathrm{C}-6\right), 17.7\left(\mathrm{CH}_{3}\right.$, C-26), $17.0\left(\mathrm{CH}_{3}, \mathrm{C}-24\right), 16.0\left(\mathrm{CH}_{3}, \mathrm{C}-25\right) ;{ }^{1} \mathrm{H}$ and ${ }^{13} \mathrm{C}$ NMR of the glycosidic part, see Table 1; HRESIMS (positive-ion mode) $\mathrm{m} / \mathrm{z} 1007.4835[\mathrm{M}+\mathrm{Na}]^{+}$(calculated for $\mathrm{C}_{49} \mathrm{H}_{76} \mathrm{O}_{20} \mathrm{Na}$, 1007.4828).

4.7. Zebirioside $C$, 3-O- $\alpha$-L-rhamnopyranosyl-(1 $\rightarrow 3)-[\beta-D-g l u c o p y r a n o s y l-(1 \rightarrow 2)]-\beta-D-$ glucuronopyranosyl serjanic acid (3): White powder; $[\alpha]_{D}{ }^{20}+7.5^{\circ}(c 0.48, \mathrm{MeOH}) ;{ }^{1} \mathrm{H} N M R$ (600 MHz, Methanol- $\left.d_{4}\right)$ of the aglycon: $\delta_{H} 5.32(1 \mathrm{H}, \mathrm{t}, J=3.5 \mathrm{~Hz}, \mathrm{H}-12), 3.72(3 \mathrm{H}, \mathrm{s}, \mathrm{H}-31)$, $3.23(1 \mathrm{H}, \mathrm{m}, \mathrm{H}-3), 2.72(1 \mathrm{H}, \mathrm{dd}, J=13.5,3.6 \mathrm{~Hz}, \mathrm{H}-18), 2.03(1 \mathrm{H}, \mathrm{td}, J=13.4,3.3 \mathrm{~Hz}, \mathrm{H \alpha}-$ 16 ), 2.02 (1H, m, Ha-21), 1.95 (1H, m, Ha-19), 1.93 (2H, m, H-11), 1.91 (1H, m, Ha-2), 1.77 $(1 \mathrm{H}, \mathrm{td}, J=13.5,4.1 \mathrm{~Hz}, \mathrm{Ha}-15), 1.75(1 \mathrm{H}, \mathrm{m}, \mathrm{H \beta}-2), 1.69(1 \mathrm{H}, \mathrm{t}, J=13.7 \mathrm{~Hz}, \mathrm{H} \beta-19), 1.67$ 
(1H, m, Hß-16), $1.66(1 \mathrm{H}, \mathrm{m}, \mathrm{H \alpha}-1), 1.64(1 \mathrm{H}, \mathrm{m}, \mathrm{H \alpha}-22), 1.62(1 \mathrm{H}, \mathrm{m}, \mathrm{H}-9), 1.60(1 \mathrm{H}, \mathrm{m}$, $\mathrm{H} \beta-22), 1.57$ (2H, m, Ha-6), $1.52(1 \mathrm{H}, \mathrm{m}, \mathrm{H \alpha}-7), 1.42(1 \mathrm{H}, \mathrm{m}, \mathrm{H} \beta-6), 1.39(1 \mathrm{H}, \mathrm{td}, J=13.4$, $4.5 \mathrm{~Hz}, \mathrm{H} \beta-21), 1.33(1 \mathrm{H}, \mathrm{dt}, J=12.7,3.9 \mathrm{~Hz}, \mathrm{H} \beta-7), 1.19(3 \mathrm{H}, \mathrm{s}, \mathrm{H}-27), 1.15(3 \mathrm{H}, \mathrm{s}, \mathrm{H}-29)$, $1.12(1 \mathrm{H}, \mathrm{dt}, J=13.5,3.7 \mathrm{~Hz}, \mathrm{H} \beta-15), 1.09(3 \mathrm{H}, \mathrm{s}, \mathrm{H}-23), 1.02(1 \mathrm{H}, \mathrm{m}, \mathrm{H} \beta-1), 0.97(3 \mathrm{H}, \mathrm{s}, \mathrm{H}-$ 25), 0.89 (3H, s, H-24), $0.82(3 \mathrm{H}, \mathrm{s}, \mathrm{H}-26), 0.81(1 \mathrm{H}, \mathrm{m}, \mathrm{H}-5) .{ }^{13} \mathrm{C} \mathrm{NMR}\left(151 \mathrm{MHz}, \mathrm{CD}_{3} \mathrm{OD}\right)$ of the aglycon: $\delta_{\mathrm{C}} 181.3(\mathrm{RCOOH}, \mathrm{C}-28), 178.8\left(\mathrm{COOCH}_{3}, \mathrm{C}-30\right), 144.7(\mathrm{HC}=\mathrm{C}, \mathrm{C}-13), 124.3$ ( $\mathrm{HC}=\mathrm{C}, \mathrm{C}-12), 92.4(\mathrm{CH}-\mathrm{O}, \mathrm{C}-3), 56.9(\mathrm{CH}, \mathrm{C}-5), 52.3\left(\mathrm{COOCH}_{3}, \mathrm{C}-31\right), 49.0(\mathrm{CH}, \mathrm{C}-9), 47.0$ (C, C-17), 45.0 (C, C-20), 44.0 (CH, C-18), $43.4\left(\mathrm{CH}_{2}, \mathrm{C}-19\right), 42.8$ (C, C-14), 40.5 (C, C-8), 40.4 (C, C-4), 37.9 (C, C-10), $39.7\left(\mathrm{CH}_{2}, \mathrm{C}-1\right), 35.0\left(\mathrm{CH}_{2}, \mathrm{C}-22\right), 34.0\left(\mathrm{CH}_{2}, \mathrm{C}-7\right), 31.3\left(\mathrm{CH}_{2}\right.$, C-21), $28.9\left(\mathrm{CH}_{2}, \mathrm{C}-15\right), 28.7\left(\mathrm{CH}_{3}, \mathrm{C}-29\right), 28.4\left(\mathrm{CH}_{3}, \mathrm{C}-23\right), 27.0\left(\mathrm{CH}_{2}, \mathrm{C}-2\right), 26.3\left(\mathrm{CH}_{3}, \mathrm{C}-\right.$ 27), $24.5\left(\mathrm{CH}_{2}, \mathrm{C}-11\right), 24.2\left(\mathrm{CH}_{2}, \mathrm{C}-16\right), 19.3\left(\mathrm{CH}_{2}, \mathrm{C}-6\right), 17.7\left(\mathrm{CH}_{3}, \mathrm{C}-26\right), 16.9\left(\mathrm{CH}_{3}, \mathrm{C}-24\right)$, $16.0\left(\mathrm{CH}_{3}, \mathrm{C}-25\right) ;{ }^{1} \mathrm{H}$ and ${ }^{13} \mathrm{C}$ NMR of the glycosidic part, see Table 1; HRESIMS (positive-ion mode) $\mathrm{m} / \mathrm{z} 1007.4832[\mathrm{M}+\mathrm{Na}]^{+}$(calculated for $\mathrm{C}_{49} \mathrm{H}_{76} \mathrm{O}_{20} \mathrm{Na}, 1007.4828$ ).

4.8. Zebirioside $D$, 3-O- $\alpha$-L-rhamnopyranosyl-(1 $\rightarrow 3)-[\beta-D-x y l o p y r a n o s y l-(1 \rightarrow 2)-] \beta-D-$ glucuronopyranosyl serjanic acid (4): White powder; $[\alpha]_{D}{ }^{20}+8.3^{\circ}(c 0.55, \mathrm{MeOH}) ;{ }^{1} \mathrm{H} N M R$ $\left(600 \mathrm{MHz}\right.$, Methanol- $\left.d_{4}\right)$ of the aglycon: $\delta_{\mathrm{H}} 5.19(1 \mathrm{H}, \mathrm{t}, J=3.4 \mathrm{~Hz}, \mathrm{H}-12), 3.59(3 \mathrm{H}, \mathrm{s}, \mathrm{H}-31)$, $3.02(1 \mathrm{H}, \mathrm{dd}, J=11.7,4.5 \mathrm{~Hz}, \mathrm{H}-3), 2.59(1 \mathrm{H}, \mathrm{dd}, J=13.5,4.3 \mathrm{~Hz}, \mathrm{H}-18), 1.91(1 \mathrm{H}, \mathrm{td}, J=$ 13.5, 3.8 Hz , Ha-16 ), 1.89 (1H, m, Ha-21), $1.83(1 \mathrm{H}, \mathrm{m}, \mathrm{Ha}-19), 1.80$ (2H, dd, J = 9.0, 3.7 $\mathrm{Hz}, \mathrm{H}-11), 1.74(1 \mathrm{H}, \mathrm{dq}, J=13.5,3.6 \mathrm{~Hz}, \mathrm{Ha}-2), 1.65(1 \mathrm{H}, \mathrm{td}, J=14.2,4.4 \mathrm{~Hz}, \mathrm{Ha}-15), 1.59$

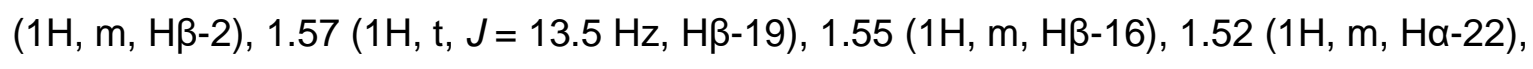
$1.51(1 \mathrm{H}, \mathrm{m}, \mathrm{Ha}-1), 1.49(2 \mathrm{H}, \mathrm{m}, \mathrm{H}-9 / \mathrm{H} \beta-22), 1.45(1 \mathrm{H}, \mathrm{m}, \mathrm{Ha}-6), 1.40(1 \mathrm{H}, \mathrm{td}, J=12.3,4.1$ $\mathrm{Hz}, \mathrm{Ha}-7), 1.30(1 \mathrm{H}, \mathrm{m}, \mathrm{H} \beta-6), 1.27(1 \mathrm{H}, \mathrm{td}, J=13.5,4.6 \mathrm{~Hz}, \mathrm{H} \beta-21), 1.21(1 \mathrm{H}, \mathrm{dt}, J=12.3$, $2.6 \mathrm{~Hz}, \mathrm{H} \beta-7), 1.07$ (3H, s, H-27), 1.03 (3H, s, H-29), 0.99 (1H, dt, J=14.2, 3.7 Hz, Hß-15), $0.95(3 \mathrm{H}, \mathrm{s}, \mathrm{H}-23), 0.88(1 \mathrm{H}, \mathrm{dd}, J=13.5,3.3 \mathrm{~Hz}, \mathrm{H} \beta-1), 0.85(3 \mathrm{H}, \mathrm{s}, \mathrm{H}-25), 0.75(3 \mathrm{H}, \mathrm{s}, \mathrm{H}-$ 24), $0.70(3 \mathrm{H}, \mathrm{s}, \mathrm{H}-26), 0.67(1 \mathrm{H}, \mathrm{m}, \mathrm{H}-5) .{ }^{13} \mathrm{C} \mathrm{NMR}\left(151 \mathrm{MHz}, \mathrm{CD}_{3} \mathrm{OD}\right)$ of the aglycon: $\delta_{\mathrm{C}}$ $181.3(\mathrm{COOH}, \mathrm{C}-28), 178.8\left(\mathrm{COOCH}_{3}, \mathrm{C}-30\right), 144.7$ (HC-C, C-13), 124.3 (HC-C, C-12), 91.9 (CH-O, C-3), $57.0(\mathrm{CH}, \mathrm{C}-5), 52.3\left(\mathrm{COOCH}_{3}, \mathrm{C}-31\right), 49.0(\mathrm{CH}, \mathrm{C}-9), 47.0(\mathrm{C}, \mathrm{C}-17), 45.0(\mathrm{C}$, C-20), 44.0 ( $\mathrm{CH}, \mathrm{C}-18), 43.4\left(\mathrm{CH}_{2}, \mathrm{C}-19\right), 42.8$ (C, C-14), 40.5 (C, C-8), 40.4 (C, C-4), 39.7 $\left(\mathrm{CH}_{2}, \mathrm{C}-1\right), 37.9$ (C, C-10), $35.0\left(\mathrm{CH}_{2}, \mathrm{C}-22\right), 34.0\left(\mathrm{CH}_{2}, \mathrm{C}-7\right), 31.3\left(\mathrm{CH}_{2}, \mathrm{C}-21\right), 28.9\left(\mathrm{CH}_{2}\right.$, C-15), $28.7\left(\mathrm{CH}_{3}, \mathrm{C}-29\right), 28.3\left(\mathrm{CH}_{3}, \mathrm{C}-23\right), 27.0\left(\mathrm{CH}_{3}, \mathrm{C}-2\right), 26.3\left(\mathrm{CH}_{3}, \mathrm{C}-27\right), 24.5\left(\mathrm{CH}_{2}, \mathrm{C}-\right.$ 11), $24.2\left(\mathrm{CH}_{2}, \mathrm{C}-16\right), 19.3\left(\mathrm{CH}_{2}, \mathrm{C}-6\right), 17.7\left(\mathrm{CH}_{3}, \mathrm{C}-26\right), 16.6\left(\mathrm{CH}_{3}, \mathrm{C}-24\right), 15.9\left(\mathrm{CH}_{3}, \mathrm{C}-25\right)$; ${ }^{1} \mathrm{H}$ and ${ }^{13} \mathrm{C}$ NMR of the glycosidic part, see Table 1 ; HRESIMS (positive-ion mode) $\mathrm{m} / \mathrm{z}$ 977.4727 [M+Na] $]^{+}$(calculated for $\mathrm{C}_{48} \mathrm{H}_{74} \mathrm{O}_{19} \mathrm{Na}, 977.4722$ ). 


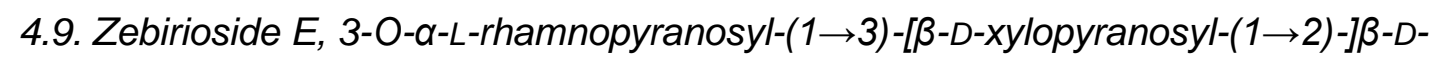
glucuronopyranosyl-28-O- $\beta$-D-glucopyranosyl serjanic acid (5): White powder; $[\alpha]_{D}^{20}+0.71^{\circ}(c$ 0.14, MeOH); ${ }^{1} \mathrm{H}$ NMR (600 MHz, Methanol- $\left.d_{4}\right) \delta 5.33(1 \mathrm{H}, \mathrm{t}, J=3.7 \mathrm{~Hz}, \mathrm{H}-12), 3.71(3 \mathrm{H}, \mathrm{s}$, $\mathrm{H}-31), 3.14(1 \mathrm{H}, \mathrm{m}, \mathrm{H}-3), 2.72(1 \mathrm{H}, \mathrm{dd}, J=13.6,4.2 \mathrm{~Hz}, \mathrm{H}-18), 2.07$ (1H, m, Ha-16 ), 2.02 (1H, m, Ha-21), $1.93(1 \mathrm{H}, \mathrm{m}, \mathrm{Ha}-19), 1.92(2 \mathrm{H}, \mathrm{dd}, J=9.1,3.7 \mathrm{~Hz}, \mathrm{H}-11), 1.87(1 \mathrm{H}, \mathrm{m}, \mathrm{Ha}-$ 2), 1.80 (1H, m, Ha-15/Hß-16), 1.73 (1H, m, Ha-22), $1.71(1 \mathrm{H}, \mathrm{m}, \mathrm{H} \beta-2), 1.70(1 \mathrm{H}, \mathrm{m}, \mathrm{H} \beta-$ 19), 1.63 (1H, m, Ha-1), 1.60 (1H, m, H-9), 1.55 (2H, m, Hß-22/Ha-6), 1.50 (1H, m, Ha-7), $1.41(1 \mathrm{H}, \mathrm{m}, \mathrm{H} \beta-6), 1.40(1 \mathrm{H}, \mathrm{m}, \mathrm{H} \beta-21), 1.33(1 \mathrm{H}, \mathrm{m}, \mathrm{H} \beta-7), 1.18(3 \mathrm{H}, \mathrm{s}, \mathrm{H}-27), 1.16(3 \mathrm{H}, \mathrm{s}$, $\mathrm{H}-29), 1.12(1 \mathrm{H}, \mathrm{m}, \mathrm{H} \beta-15), 1.06$ (3H, s, H-23), 1.00 (1H, m, Hß-1), 0.97 (3H, s, H-25), 0.86 $(3 \mathrm{H}, \mathrm{s}, \mathrm{H}-24), 0.80(3 \mathrm{H}, \mathrm{s}, \mathrm{H}-26), 0.78(1 \mathrm{H}, \mathrm{m}, \mathrm{H}-5) .{ }^{13} \mathrm{C} \mathrm{NMR}\left(151 \mathrm{MHz}, \mathrm{CD}_{3} \mathrm{OD}\right)$ of the aglycon: $\delta_{\mathrm{C}} 178.7\left(\mathrm{COOCH}_{3}, \mathrm{C}-30\right), 177.5$ (COOR, C-28), 144.7 (HC=C, C-13), 124.3 $(\mathrm{HC}=\mathrm{C}, \mathrm{C}-12), 91.8(\mathrm{CH}-\mathrm{O}, \mathrm{C}-3), 57.0(\mathrm{CH}, \mathrm{C}-5), 52.3\left(\mathrm{COOCH}_{3}, \mathrm{C}-31\right), 49.0(\mathrm{CH}, \mathrm{C}-9), 47.0$ (C, C-17), 45.0 (C, C-20), 43.9 (CH, C-18), $43.3\left(\mathrm{CH}_{2}, \mathrm{C}-19\right), 42.7$ (C, C-14), 40.5 (C, C-8), 40.4 (C, C-4), $39.8\left(\mathrm{CH}_{2}, \mathrm{C}-1\right), 37.9(\mathrm{C}, \mathrm{C}-10), 34.9\left(\mathrm{CH}_{2}, \mathrm{C}-22\right), 33.9\left(\mathrm{CH}_{2}, \mathrm{C}-7\right), 31.3\left(\mathrm{CH}_{2}\right.$, C-21), $28.9\left(\mathrm{CH}_{2}, \mathrm{C}-15\right), 28.6\left(\mathrm{CH}_{3}, \mathrm{C}-29\right), 28.3\left(\mathrm{CH}_{3}, \mathrm{C}-23\right), 27.0\left(\mathrm{CH}_{2}, \mathrm{C}-2\right), 26.2\left(\mathrm{CH}_{3}, \mathrm{C}-\right.$ 27), $24.5\left(\mathrm{CH}_{2}, \mathrm{C}-11\right), 24.1\left(\mathrm{CH}_{2}, \mathrm{C}-16\right), 19.3\left(\mathrm{CH}_{2}, \mathrm{C}-6\right), 17.7\left(\mathrm{CH}_{3}, \mathrm{C}-26\right), 16.6\left(\mathrm{CH}_{3}, \mathrm{C}-24\right)$, $15.9\left(\mathrm{CH}_{3}, \mathrm{C}-25\right) ;{ }^{1} \mathrm{H}$ and ${ }^{13} \mathrm{C}$ NMR of the glycosidic part, see Table 1; HRESIMS (positive-ion mode) $\mathrm{m} / \mathrm{z} 1139.5260[\mathrm{M}+\mathrm{Na}]^{+}$(calculated for $\mathrm{C}_{54} \mathrm{H}_{84} \mathrm{O}_{24} \mathrm{Na} 1139.5250$ ).

4.10. Zebirioside $F$, 3-O- $\beta-D-x y l o p y r a n o s y l-(1 \rightarrow 3)-\alpha-L-r h a m n o p y r a n o s y l-(1 \rightarrow 3)-[\beta-D-$ glucopyranosyl-(1 $\rightarrow 2)-] \beta$-D-glucuronopyranosyl serjanic acid $(6)$ : White powder; $[\alpha]_{\mathrm{D}}{ }^{20}+8.6^{\circ}$ (c $0.29, \mathrm{MeOH}) ;{ }^{1} \mathrm{H}$ NMR $\left(600 \mathrm{MHz}\right.$, Methanol- $\left.d_{4}\right)$ of the aglycon: $\delta_{\mathrm{H}} 5.32(1 \mathrm{H}, \mathrm{t}, J=3.8 \mathrm{~Hz}$, $\mathrm{H}-12), 3.72(3 \mathrm{H}, \mathrm{s}, \mathrm{H}-31), 3.23(1 \mathrm{H}, \mathrm{dd}, J=12.1,4.6 \mathrm{~Hz}, \mathrm{H}-3), 2.71(1 \mathrm{H}, \mathrm{dd}, J=13.4,4.1 \mathrm{~Hz}$, $\mathrm{H}-18), 2.03(1 \mathrm{H}, \mathrm{dd}, J=13.4,3.5 \mathrm{~Hz}, \mathrm{Ha}-16), 2.01(1 \mathrm{H}, \mathrm{m}, \mathrm{Ha}-21), 1.95(1 \mathrm{H}, \mathrm{m}, \mathrm{Ha}-19)$, $1.93(2 \mathrm{H}, \mathrm{dd}, J=9.2,3.8 \mathrm{~Hz}, \mathrm{H}-11), 1.90(1 \mathrm{H}, \mathrm{m}, \mathrm{Ha}-2), 1.77(1 \mathrm{H}, \mathrm{m}, \mathrm{Ha}-15), 1.75(1 \mathrm{H}, \mathrm{m}$, $\mathrm{H} \beta-2), 1.69(1 \mathrm{H}, \mathrm{t}, J=13.9 \mathrm{~Hz}, \mathrm{H} \beta-19), 1.67(1 \mathrm{H}, \mathrm{m}, \mathrm{H \beta}-16), 1.66(1 \mathrm{H}, \mathrm{m}, \mathrm{H \alpha}-1), 1.64(1 \mathrm{H}$, m, Ha-22), $1.62(1 \mathrm{H}, \mathrm{m}, \mathrm{H}-9), 1.60(1 \mathrm{H}, \mathrm{m}, \mathrm{H \beta}-22), 1.57(1 \mathrm{H}, \mathrm{m}, \mathrm{H \alpha}-6), 1.52(1 \mathrm{H}, \mathrm{td}, J=$ 12.7, 4.1 Hz, Ha-7), $1.43(1 \mathrm{H}, \mathrm{m}, \mathrm{H} \beta-6), 1.39(1 \mathrm{H}, \mathrm{td}, J=13.4,4.6 \mathrm{~Hz}, \mathrm{H} \beta-21), 1.33(1 \mathrm{H}, \mathrm{m}$, $\mathrm{H} \beta-7), 1.19(3 \mathrm{H}, \mathrm{s}, \mathrm{H}-27), 1.15(3 \mathrm{H}, \mathrm{s}, \mathrm{H}-29), 1.12(1 \mathrm{H}, \mathrm{td}, J=14.1,3.5 \mathrm{~Hz}, \mathrm{H} \beta-15), 1.09(3 \mathrm{H}$, s, H-23), $1.03(1 \mathrm{H}, \mathrm{td}, J=13.2,3.4 \mathrm{~Hz}, \mathrm{H} \beta-1), 0.97(3 \mathrm{H}, \mathrm{s}, \mathrm{H}-25), 0.89(3 \mathrm{H}, \mathrm{s}, \mathrm{H}-24), 0.82$ $(3 \mathrm{H}, \mathrm{s}, \mathrm{H}-26), 0.81(1 \mathrm{H}, \mathrm{m}, \mathrm{H}-5) .{ }^{13} \mathrm{C}$ NMR $\left(151 \mathrm{MHz}, \mathrm{CD}_{3} \mathrm{OD}\right)$ of the aglycon: $\delta_{\mathrm{C}} 181.3$ (COOH, C-28), $178.8\left(\mathrm{COOCH}_{3}, \mathrm{C}-30\right), 144.7$ (HC-C, C-13), 124.3 (HC-C, C-12), 92.5 (CHO, C-3), 56.9 ( $\mathrm{CH}, \mathrm{C}-5), 52.3\left(\mathrm{COOCH}_{3}, \mathrm{C}-31\right), 49.0$ (CH, C-9), 47.0 (C, C-17), 45.0 (C, C20), 44.0 ( $\mathrm{CH}, \mathrm{C}-18), 43.4\left(\mathrm{CH}_{2}, \mathrm{C}-19\right), 42.8$ (C, C-14), 40.7 (C, C-8), 40.5 (C, C-4), 39.7 $\left(\mathrm{CH}_{2}, \mathrm{C}-1\right), 37.9(\mathrm{C}, \mathrm{C}-10), 35.0\left(\mathrm{CH}_{2}, \mathrm{C}-22\right), 34.0\left(\mathrm{CH}_{2}, \mathrm{C}-7\right), 31.3\left(\mathrm{CH}_{2}, \mathrm{C}-21\right), 28.9\left(\mathrm{CH}_{2}\right.$, C-15), $28.7\left(\mathrm{CH}_{3}, \mathrm{C}-29\right), 28.4\left(\mathrm{CH}_{3}, \mathrm{C}-23\right), 27.0\left(\mathrm{CH}_{2}, \mathrm{C}-2\right), 26.3\left(\mathrm{CH}_{3}, \mathrm{C}-27\right), 24.5\left(\mathrm{CH}_{2}, \mathrm{C}-\right.$ 
11), $24.2\left(\mathrm{CH}_{2}, \mathrm{C}-16\right), 19.3\left(\mathrm{CH}_{2}, \mathrm{C}-6\right), 17.7\left(\mathrm{CH}_{3}, \mathrm{C}-26\right), 16.9\left(\mathrm{CH}_{3}, \mathrm{C}-24\right), 15.9\left(\mathrm{CH}_{3}, \mathrm{C}-25\right)$; ${ }^{1} \mathrm{H}$ and ${ }^{13} \mathrm{C}$ NMR of the glycosidic part, see Table 1 ; HRESIMS (positive-ion mode) $\mathrm{m} / \mathrm{z}$ $1139.5242[\mathrm{M}+\mathrm{Na}]^{+}$(calculated for $\mathrm{C}_{54} \mathrm{H}_{84} \mathrm{O}_{24} \mathrm{Na}, 1139.5250$ ).

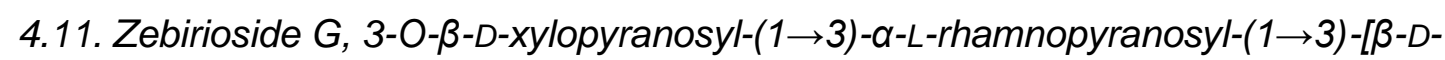
xylopyranosyl-(1 $\rightarrow 2)-] \beta-D$-glucuronopyranosyl serjanic acid $(7)$ : White powder; $[\alpha]_{D}{ }^{20}+95^{\circ}(c$ 0.02, $\mathrm{MeOH}) ;{ }^{1} \mathrm{H}$ NMR $\left(600 \mathrm{MHz}\right.$, Methanol- $\left.d_{4}\right)$ of the aglycon: $\delta_{\mathrm{H}} 5.31(1 \mathrm{H}, \mathrm{t}, J=3.7 \mathrm{~Hz}, \mathrm{H}-$ 12), $3.72(3 \mathrm{H}, \mathrm{s}, \mathrm{H}-31), 3.14(1 \mathrm{H}, \mathrm{dd}, J=13.8,3.7 \mathrm{~Hz}, \mathrm{H}-3), 2.71(1 \mathrm{H}, \mathrm{dd}, J=13.4,4.1 \mathrm{~Hz}$, $\mathrm{H}-18), 2.02(1 \mathrm{H}, \mathrm{dd}, J=13.8,4.1 \mathrm{~Hz}, \mathrm{Ha}-16$ ), 2.01 (1H, m, Ha-21), 1.95 (1H, m, Ha-19), $1.92(2 \mathrm{H}, \mathrm{dd}, J=9.2,3.8 \mathrm{~Hz}, \mathrm{H}-11), 1.87(1 \mathrm{H}, \mathrm{dq}, J=13.8,3.7 \mathrm{~Hz}, \mathrm{Ha}-2), 1.77(1 \mathrm{H}, \mathrm{td}, J=$

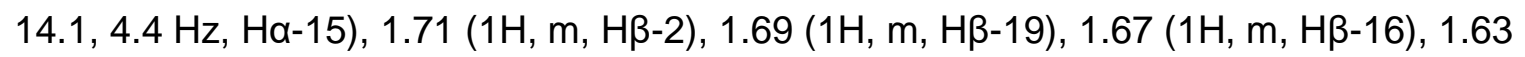
(1H, m, Ha-22/Ha-1), $1.61(1 \mathrm{H}, \mathrm{m}, \mathrm{H}-9), 1.60$ (1H, m, Hß-22), 1.57 (1H, m, Ha-6), $1.52(1 \mathrm{H}$, $\mathrm{td}, J=12.7,4.1 \mathrm{~Hz}, \mathrm{Ha}-7), 1.42(1 \mathrm{H}, \mathrm{m}, \mathrm{H} \beta-6), 1.39(1 \mathrm{H}, \mathrm{td}, J=13.4,4.6 \mathrm{~Hz}, \mathrm{H} \beta-21), 1.32$ $(1 \mathrm{H}, \mathrm{m}, \mathrm{H} \beta-7), 1.18(3 \mathrm{H}, \mathrm{s}, \mathrm{H}-27), 1.16(3 \mathrm{H}, \mathrm{s}, \mathrm{H}-29), 1.12(1 \mathrm{H}, \mathrm{td}, J=14.1,3.5 \mathrm{~Hz}, \mathrm{H} \beta-15)$, $1.08(3 \mathrm{H}, \mathrm{s}, \mathrm{H}-23), 1.00(1 \mathrm{H}, \mathrm{td}, J=13.2,3.4 \mathrm{~Hz}, \mathrm{H} \beta-1), 0.97(3 \mathrm{H}, \mathrm{s}, \mathrm{H}-25), 0.86(3 \mathrm{H}, \mathrm{s}, \mathrm{H}-$ 24), $0.82(3 \mathrm{H}, \mathrm{s}, \mathrm{H}-26), 0.79(1 \mathrm{H}, \mathrm{m}, \mathrm{H}-5) .{ }^{13} \mathrm{C} \mathrm{NMR}\left(151 \mathrm{MHz}, \mathrm{CD}_{3} \mathrm{OD}\right)$ of the aglycon: $\delta_{\mathrm{C}}$ $181.3(\mathrm{COOH}, \mathrm{C}-28), 178.8\left(\mathrm{COOCH}_{3}, \mathrm{C}-30\right), 144.7$ (HC-C, C-13), 124.3 (HC-C, C-12), 91.9 (CH-O, C-3), $57.0(\mathrm{CH}, \mathrm{C}-5), 52.3\left(\mathrm{COOCH}_{3}, \mathrm{C}-31\right), 49.0(\mathrm{CH}, \mathrm{C}-9), 47.0(\mathrm{C}, \mathrm{C}-17), 45.0$ (C, C-20), 44.0 ( $\mathrm{CH}, \mathrm{C}-18), 43.4\left(\mathrm{CH}_{2}, \mathrm{C}-19\right), 42.8$ (C, C-14), 40.5 (C, C-8), 40.4 (C, C-4), 39.7 $\left(\mathrm{CH}_{2}, \mathrm{C}-1\right), 37.9$ (C, C-10), $35.0\left(\mathrm{CH}_{2}, \mathrm{C}-22\right), 34.0\left(\mathrm{CH}_{2}, \mathrm{C}-7\right), 31.3\left(\mathrm{CH}_{2}, \mathrm{C}-21\right), 28.9\left(\mathrm{CH}_{2}\right.$, C-15), $28.7\left(\mathrm{CH}_{3}, \mathrm{C}-29\right), 28.3\left(\mathrm{CH}_{3}, \mathrm{C}-23\right), 27.0\left(\mathrm{CH}_{2}, \mathrm{C}-2\right), 26.3\left(\mathrm{CH}_{3}, \mathrm{C}-27\right), 24.5\left(\mathrm{CH}_{2}, \mathrm{C}-\right.$ 11), $24.2\left(\mathrm{CH}_{2}, \mathrm{C}-16\right), 19.3\left(\mathrm{CH}_{2}, \mathrm{C}-6\right), 17.7\left(\mathrm{CH}_{3}, \mathrm{C}-26\right), 16.7\left(\mathrm{CH}_{3}, \mathrm{C}-24\right), 15.9\left(\mathrm{CH}_{3}, \mathrm{C}-25\right)$; ${ }^{1} \mathrm{H}$ and ${ }^{13} \mathrm{C}$ NMR of the glycosidic part, see Table 2; HRESIMS (positive-ion mode) $\mathrm{m} / \mathrm{z}$ $1109.5149[\mathrm{M}+\mathrm{Na}]^{+}$(calculated for $\mathrm{C}_{53} \mathrm{H}_{82} \mathrm{O}_{23} \mathrm{Na}, 1109.4984$ ).

4.12. Zebirioside $H$, 3-O- $\beta-D-x y l o p y r a n o s y l-(1 \rightarrow 3)-\alpha-L-r h a m n o p y r a n o s y l-(1 \rightarrow 3)-[\beta-D-$ glucopyranosyl-(1 $\rightarrow 2)-] \beta$-D-glucuronopyranosyl-28-O- $\beta$-D-glucopyranosyl serjanic acid (8): White powder; $[\alpha]_{D}{ }^{20}+8.2^{\circ}\left(c 0.45\right.$, MeOH); ${ }^{1} \mathrm{H}$ NMR $\left(600 \mathrm{MHz}\right.$, Methanol- $\left.d_{4}\right)$ of the aglycon: $\delta_{H} 5.33(1 \mathrm{H}, \mathrm{t}, J=3.5 \mathrm{~Hz}, \mathrm{H}-12), 3.71(3 \mathrm{H}, \mathrm{s}, \mathrm{H}-31), 3.22(1 \mathrm{H}, \mathrm{dd}, J=12.3,4.3 \mathrm{~Hz}, \mathrm{H}-3)$, $2.72(1 \mathrm{H}, \mathrm{dd}, J=13.5,3.5 \mathrm{~Hz}, \mathrm{H}-18), 2.06(1 \mathrm{H}, \mathrm{td}, J=14.4,3.5 \mathrm{~Hz}, \mathrm{Ha}-16), 2.02(1 \mathrm{H}, \mathrm{m}$, Ha-21), 1.97 (1H , m, Ha-19), 1.93 (2H, dd, J=9.1, 3.7 Hz, H-11), 1.90 (1H, m, Ha-2), 1.80

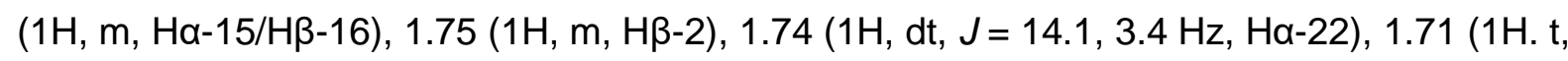
$J=13.8 \mathrm{~Hz}, \mathrm{H} \beta-19), 1.66(1 \mathrm{H}, \mathrm{m}, \mathrm{H \alpha}-1), 1.61(1 \mathrm{H}, \mathrm{t}, J=9.1 \mathrm{~Hz}, \mathrm{H}-9), 1.55(1 \mathrm{H}, \mathrm{td}, J=14.1$, $4.0 \mathrm{~Hz}, \mathrm{H \beta}-22), 1.55$ (1H, m, Ha-6), 1.49 (1H, dd, $J=12.5,3.6 \mathrm{~Hz}, \mathrm{H \alpha}-7), 1.41(1 \mathrm{H}, \mathrm{m}, \mathrm{H} \beta-$ 6), $1.40(1 \mathrm{H}, \mathrm{m}, \mathrm{H} \beta-21), 1.33(1 \mathrm{H}, \mathrm{m}, \mathrm{H} \beta-7), 1.18(3 \mathrm{H}, \mathrm{s}, \mathrm{H}-27), 1.15(3 \mathrm{H}, \mathrm{s}, \mathrm{H}-29), 1.11(1 \mathrm{H}$, m, H $3-15), 1.03(3 \mathrm{H}, \mathrm{s}, \mathrm{H}-23), 1.01(1 \mathrm{H}, \mathrm{td}, J=15.4,4.2 \mathrm{~Hz}, \mathrm{H} \beta-1), 0.97$ (3H, s, H-25), 0.87 
(3H, s, H-24), 0.81 (3H, s, H-26), $0.80(1 \mathrm{H}, \mathrm{m}, \mathrm{H}-5) .{ }^{13} \mathrm{C}$ NMR (151 MHz, $\left.\mathrm{CD}_{3} \mathrm{OD}\right)$ of the aglycon: $\delta_{\mathrm{C}} 178.7\left(\mathrm{COOCH}_{3}, \mathrm{C}-30\right), 177.5$ (COOR, C-28), $144.4(\mathrm{HC}=\mathrm{C}, \mathrm{C}-13), 124.4$ ( $\mathrm{HC}=\mathrm{C}, \mathrm{C}-12), 92.5(\mathrm{CH}-\mathrm{O}, \mathrm{C}-3), 57.0(\mathrm{CH}, \mathrm{C}-5), 52.4\left(\mathrm{COOCH}_{3}, \mathrm{C}-31\right), 49.0(\mathrm{CH}, \mathrm{C}-9), 47.4$ (C, C-17), 45.0 (C, C-20), 43.9 ( $\mathrm{CH}, \mathrm{C}-18), 43.3\left(\mathrm{CH}_{2}, \mathrm{C}-19\right), 42.8$ (C, C-14), 40.7 (C, C-8), 40.5 (C, C-4), $39.8\left(\mathrm{CH}_{2}, \mathrm{C}-1\right), 37.9$ (C, C-10), $34.4\left(\mathrm{CH}_{2}, \mathrm{C}-22\right), 33.9\left(\mathrm{CH}_{2}, \mathrm{C}-7\right), 31.3\left(\mathrm{CH}_{2}\right.$, C-21), $29.0\left(\mathrm{CH}_{2}, \mathrm{C}-15\right), 28.6\left(\mathrm{CH}_{3}, \mathrm{C}-29\right), 28.4\left(\mathrm{CH}_{3}, \mathrm{C}-23\right), 27.0\left(\mathrm{CH}_{2}, \mathrm{C}-2\right), 26.2\left(\mathrm{CH}_{3}, \mathrm{C}-\right.$ 27), $24.6\left(\mathrm{CH}_{2}, \mathrm{C}-11\right), 24.1\left(\mathrm{CH}_{2}, \mathrm{C}-16\right), 19.3\left(\mathrm{CH}_{2}, \mathrm{C}-6\right), 17.7\left(\mathrm{CH}_{3}, \mathrm{C}-26\right), 16.9\left(\mathrm{CH}_{3}, \mathrm{C}-24\right)$, $16.0\left(\mathrm{CH}_{3}, \mathrm{C}-25\right) ;{ }^{1} \mathrm{H}$ and ${ }^{13} \mathrm{C}$ NMR of the glycosidic part, see Table 2; HRESIMS (positive-ion mode) $\mathrm{m} / \mathrm{z} 1301.5768[\mathrm{M}+\mathrm{Na}]^{+}$(calculated for $\mathrm{C}_{60} \mathrm{H}_{94} \mathrm{O}_{29} \mathrm{Na}, 1301.5778$ ).

4.13. Zebirioside I, 3-O- $\beta-D-x y l o p y r a n o s y l-(1 \rightarrow 3)-\alpha-L-r h a m n o p y r a n o s y l-(1 \rightarrow 3)-[\beta-D-$ xylopyranosyl-(1 $\rightarrow 2)-] \beta-D$-glucuronopyranosyl-28-O- $\beta$-D-glucopyranosyl serjanic acid (9): White powder; $[\alpha]_{D}{ }^{20}+9.3^{\circ}(c 0.68, \mathrm{MeOH}) ;{ }^{1} \mathrm{H} \mathrm{NMR}\left(600 \mathrm{MHz}\right.$, Methanol- $\left.d_{4}\right)$ of the aglycon: $\delta_{H} 5.33(1 \mathrm{H}, \mathrm{t}, J=3.5 \mathrm{~Hz}, \mathrm{H}-12), 3.71(3 \mathrm{H}, \mathrm{s}, \mathrm{H}-31), 3.13(1 \mathrm{H}, \mathrm{m}, \mathrm{H}-3), 2.72(1 \mathrm{H}, \mathrm{dd}, J=$ 13.5, 3.3 Hz, H-18), 2.06 (1H, m, Ha-16 ), 2.02 (1H, m, Ha-21), 1.97 (1H , m, Ha-19), 1.92

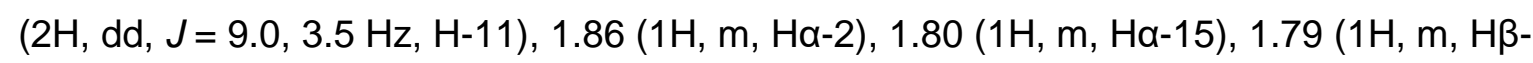
16), 1.73 (1H, m, Ha-22), $1.72(1 \mathrm{H}, \mathrm{m}, \mathrm{H} \beta-2), 1.70(1 \mathrm{H}, \mathrm{m}, \mathrm{H} \beta-19), 1.64$ (1H, m, Ha-1), 1.60 (1H, m, H-9), $1.55(1 \mathrm{H}, \mathrm{m}, \mathrm{H} \beta-22 / \mathrm{Ha}-6), 1.50(1 \mathrm{H}, \mathrm{m}, \mathrm{Ha}-7), 1.41(1 \mathrm{H}, \mathrm{m}, \mathrm{H} \beta-6), 1.40(1 \mathrm{H}$, $\mathrm{m}, \mathrm{H} \beta-21), 1.33(1 \mathrm{H}, \mathrm{m}, \mathrm{H} \beta-7), 1.18(3 \mathrm{H}, \mathrm{s}, \mathrm{H}-27), 1.15(3 \mathrm{H}, \mathrm{s}, \mathrm{H}-29), 1.12(1 \mathrm{H}, \mathrm{m}, \mathrm{H} \beta-15)$, 1.06 (3H, s, H-23), 1.00 (1H, m, Hß-1), 0.97 (3H, s, H-25), $0.86(3 \mathrm{H}, \mathrm{s}, \mathrm{H}-24), 0.80(3 \mathrm{H}, \mathrm{s}, \mathrm{H}-$ 26), $0.79(1 \mathrm{H}, \mathrm{m}, \mathrm{H}-5) .{ }^{13} \mathrm{C} N M R\left(151 \mathrm{MHz}, \mathrm{CD}_{3} \mathrm{OD}\right)$ of the aglycon: $\delta_{\mathrm{C}} 178.7\left(\mathrm{COOCH}_{3}, \mathrm{C}-\right.$ 30), 177.5 (COOR, C-28), 144.4 ( $\mathrm{HC}=\mathrm{C}, \mathrm{C}-13$ ), 124.4 (HC=C, C-12), 91.9 (CH-O, C-3), 57.1 $(\mathrm{CH}, \mathrm{C}-5), 52.4\left(\mathrm{COOCH}_{3}, \mathrm{C}-31\right), 49.0(\mathrm{CH}, \mathrm{C}-9), 47.4$ (C, C-17), 45.0 (C, C-20), $43.9(\mathrm{CH}$, C-18), $43.3\left(\mathrm{CH}_{2}, \mathrm{C}-19\right), 42.8$ (C, C-14), 40.7 (C, C-8), 40.4 (C, C-4), $39.8\left(\mathrm{CH}_{2}, \mathrm{C}-1\right), 37.9$ (C, C-10), $34.4\left(\mathrm{CH}_{2}, \mathrm{C}-22\right), 34.0\left(\mathrm{CH}_{2}, \mathrm{C}-7\right), 31.3\left(\mathrm{CH}_{2}, \mathrm{C}-21\right), 29.0\left(\mathrm{CH}_{2}, \mathrm{C}-15\right), 28.6\left(\mathrm{CH}_{3}\right.$, C-29), $28.4\left(\mathrm{CH}_{3}, \mathrm{C}-23\right), 27.1\left(\mathrm{CH}_{2}, \mathrm{C}-2\right), 26.2\left(\mathrm{CH}_{3}, \mathrm{C}-27\right), 24.5\left(\mathrm{CH}_{2}, \mathrm{C}-11\right), 24.1\left(\mathrm{CH}_{2}, \mathrm{C}-\right.$ 16), $19.4\left(\mathrm{CH}_{2}, \mathrm{C}-6\right), 17.7\left(\mathrm{CH}_{3}, \mathrm{C}-26\right), 16.7\left(\mathrm{CH}_{3}, \mathrm{C}-24\right), 16.0\left(\mathrm{CH}_{3}, \mathrm{C}-25\right) ;{ }^{1} \mathrm{H}$ and ${ }^{13} \mathrm{C} \mathrm{NMR}$ of the glycosidic part, see Table 2; HRESIMS (negative-ion mode) $\mathrm{m} / \mathrm{z} 1247.5775$ [M-H] (calculated for $\mathrm{C}_{59} \mathrm{H}_{92} \mathrm{O}_{28}, 1247.5773$ ).

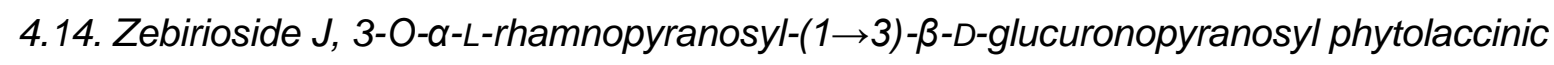
acid (10): White powder; $[\alpha]_{D}{ }^{20}+14.3^{\circ}(c 0.76, \mathrm{MeOH}) ;{ }^{1} \mathrm{H}$ NMR $\left(600 \mathrm{MHz}\right.$, Méthanol- $\left.d_{4}\right)$ of the aglycon: $\delta_{H} 5.19(1 \mathrm{H}, \mathrm{t}, J=3.6 \mathrm{~Hz}, \mathrm{H}-12), 3.59(3 \mathrm{H}, \mathrm{s}, \mathrm{H}-31), 3.53(1 \mathrm{H}, \mathrm{dd}, J=11.8,4.5$ $\mathrm{Hz}, \mathrm{H}-3), 3.51(1 \mathrm{H}, \mathrm{d}, J=11.5 \mathrm{~Hz}, \mathrm{Ha}-23), 3.18(1 \mathrm{H}, \mathrm{d}, J=11.5 \mathrm{~Hz}, \mathrm{H \beta}-23), 2.59(1 \mathrm{H}, \mathrm{dd}, J$ $=13.5,3.2 \mathrm{~Hz}, \mathrm{H}-18), 1.90(1 \mathrm{H}, \mathrm{td}, J=13.2,3.6 \mathrm{~Hz}, \mathrm{Ha}-16), 1.89(1 \mathrm{H}, \mathrm{dm}, J=13.2 \mathrm{~Hz}, \mathrm{Ha}-$ 21), 1.83 (2H , m , Ha-19/Ha-11), 1.80 (1H. m. Hß-11), 1.76 (1H, m, Ha-2), 1.65 (1H, m, td, J 


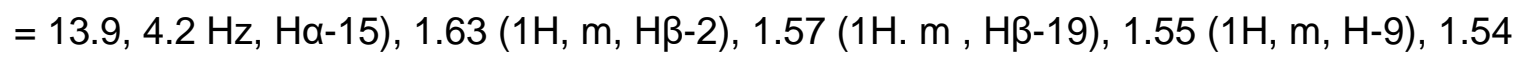
(1H, m, Hß-16), 1.52 (1H. m , Ha-22) , $1.51(2 \mathrm{H}, \mathrm{m}, \mathrm{Ha}-1 / \mathrm{Ha}-7), 1.48(1 \mathrm{H}, \mathrm{td}, J=13.8,4.2$ $\mathrm{Hz}, \mathrm{H} \beta-22), 1.39$ (1H, m, Ha-6), $1.27(1 \mathrm{H}, \mathrm{m}, \mathrm{H} \beta-21), 1.26(1 \mathrm{H}, \mathrm{m}, \mathrm{H} \beta-6), 1.15(1 \mathrm{H}, \mathrm{m}, \mathrm{H} \beta-$ 7) , $1.14(1 \mathrm{H}, \mathrm{m}, \mathrm{H}-5), 1.09(3 \mathrm{H}, \mathrm{s}, \mathrm{H}-27), 1.04(3 \mathrm{H}, \mathrm{s}, \mathrm{H}-29), 1.00(1 \mathrm{H}, \mathrm{dt}, J=13.9,3.5 \mathrm{~Hz}$, $\mathrm{H} \beta-15), 0.87$ (4H, s, H-25/Hß-1), 0.70 (3H, s, H-26), 0.60 (3H, s, H-24). ${ }^{13} \mathrm{C} \mathrm{NMR}(151 \mathrm{MHz}$, $\left.\mathrm{CD}_{3} \mathrm{OD}\right)$ of the aglycon: $\delta_{\mathrm{C}} 181.3(\mathrm{COOH}, \mathrm{C}-28), 178.8\left(\mathrm{COOCH}_{3}, \mathrm{C}-30\right), 144.8(\mathrm{HC}=\mathrm{C}, \mathrm{C}-$ 13), 124.2 ( $\mathrm{HC}=\mathrm{C}, \mathrm{C}-12), 83.4(\mathrm{CH}-\mathrm{O}, \mathrm{C}-3), 64.6\left(\mathrm{CH}_{2}-\mathrm{O}, \mathrm{C}-23\right), 52.3\left(\mathrm{COOCH}_{3}, \mathrm{C}-31\right), 49.0$ ( $\mathrm{CH}, \mathrm{C}-9), 48.0(\mathrm{CH}, \mathrm{C}-5), 47.0$ (C, C-17), 45.0 (C, C-20), 44.0 (CH, C-18), 44.0 (C, C-4), $43.4\left(\mathrm{CH}_{2}, \mathrm{C}-19\right), 42.9$ (C, C-14), 40.5 (C, C-8), $39.5\left(\mathrm{CH}_{2}, \mathrm{C}-1\right), 37.7$ (C, C-10), $35.0\left(\mathrm{CH}_{2}\right.$, C-22), $33.4\left(\mathrm{CH}_{2}, \mathrm{C}-7\right), 31.3\left(\mathrm{CH}_{2}, \mathrm{C}-21\right), 28.9\left(\mathrm{CH}_{2}, \mathrm{C}-15\right), 28.7\left(\mathrm{CH}_{3}, \mathrm{C}-29\right), 26.4\left(\mathrm{CH}_{2}, \mathrm{C}-\right.$ 2), $26.4\left(\mathrm{CH}_{3}, \mathrm{C}-27\right), 24.5\left(\mathrm{CH}_{2}, \mathrm{C}-11\right), 24.2\left(\mathrm{CH}_{2}, \mathrm{C}-16\right), 18.8\left(\mathrm{CH}_{2}, \mathrm{C}-6\right), 17.9\left(\mathrm{CH}_{3}, \mathrm{C}-26\right)$, $16.4\left(\mathrm{CH}_{3}, \mathrm{C}-25\right), 13.4\left(\mathrm{CH}_{3}, \mathrm{C}-24\right) ;{ }^{1} \mathrm{H}$ and ${ }^{13} \mathrm{C}$ NMR of the glycosidic part, see Table 2; HRESIMS (positive-ion mode) $\mathrm{m} / z$ 861.4241[M+Na] ${ }^{+}$(calculated for $\mathrm{C}_{43} \mathrm{H}_{66} \mathrm{O}_{16} \mathrm{Na}, 861.4249$ ).

\subsection{Zebirioside K, 3-O- $\alpha$-L-rhamnopyranosyl- $\beta$-D-glucuronopyranosyl-28-O- $\beta-D-$} glucopyranosyl phytolaccinic acid (11): White powder; $[\alpha]_{D}{ }^{20}+15.9^{\circ}(c 0.88, \mathrm{MeOH}) ;{ }^{1} \mathrm{H}$ NMR (600 MHz, Methanol- $\left.d_{4}\right) \delta 5.33(1 \mathrm{H}, \mathrm{t}, J=3.3 \mathrm{~Hz}, \mathrm{H}-12), 3.71(4 \mathrm{H}, \mathrm{m}, \mathrm{H}-31), 3.65(1 \mathrm{H}, \mathrm{dd}, J$ $=10.9,4.6 \mathrm{~Hz}, \mathrm{H}-3), 3.61(1 \mathrm{H}, \mathrm{d}, J=11.5 \mathrm{~Hz}, \mathrm{Ha}-23), 3.29(1 \mathrm{H}, \mathrm{d}, J=11.5 \mathrm{~Hz}, \mathrm{H \beta}-23), 2.72$ $(1 \mathrm{H}, \mathrm{dd}, J=13.7,3.7 \mathrm{~Hz}, \mathrm{H}-18), 2.07(1 \mathrm{H}, \mathrm{td}, J=14.5,3.6 \mathrm{~Hz}, \mathrm{Ha}-16), 2.02(1 \mathrm{H}, \mathrm{m}, \mathrm{Ha}-21)$, $1.97(1 \mathrm{H}, \mathrm{m}, \mathrm{Ha}-19), 1.93(2 \mathrm{H}, \mathrm{m}, \mathrm{H}-11), 1.86(1 \mathrm{H}, \mathrm{dq}, J=13.8,4.3 \mathrm{~Hz}, \mathrm{Ha}-2), 1.79(2 \mathrm{H}, \mathrm{m}$, $\mathrm{H \alpha}-15 / \mathrm{H} \beta-16), 1.75(1 \mathrm{H}, \mathrm{m}, \mathrm{H} \beta-2), 1.73(1 \mathrm{H}, \mathrm{dt}, J=13.9,3.8 \mathrm{~Hz}, \mathrm{Ha}-22), 1.71(1 \mathrm{H}, \mathrm{m}, \mathrm{H} \beta-$ 19) , $1.66(1 \mathrm{H}, \mathrm{m}, \mathrm{H}-9), 1.63(1 \mathrm{H}, \mathrm{m}, \mathrm{H \alpha}-1), 1.62(1 \mathrm{H}, \mathrm{m}, \mathrm{H \alpha}-7), 1.55(1 \mathrm{H}, \mathrm{td}, J=13.9,3.9$ $\mathrm{Hz}, \mathrm{H} \beta-22), 1.48$ (1H, m, Ha-6), 1.40 (1H, td, J=13.6, $3.7 \mathrm{~Hz}, \mathrm{H} \beta-21), 1.37(1 \mathrm{H}, \mathrm{m}, \mathrm{H} \beta-6)$, $1.29(1 \mathrm{H}, \mathrm{m}, \mathrm{H} \beta-7), 1.26(1 \mathrm{H}, \mathrm{m}, \mathrm{H}-5), 1.20(3 \mathrm{H}, \mathrm{s}, \mathrm{H}-27), 1.16(3 \mathrm{H}, \mathrm{s}, \mathrm{H}-29), 1.12(1 \mathrm{H}, \mathrm{dt}$, $J=13.9,3.1 \mathrm{~Hz}, \mathrm{H} \beta-15), 0.99(3 \mathrm{H}, \mathrm{s}, \mathrm{H}-25), 0.98$ (1H, m, Hß-1), 0.80 (3H, s, H-26), 0.71 $(3 \mathrm{H}, \mathrm{s}, \mathrm{H}-24) .{ }^{13} \mathrm{C}$ NMR (151 MHz, MeOD) $\delta 178.8\left(\mathrm{COOCH}_{3}, \mathrm{C}-30\right), 177.6$ (COOR, C-28), $144.5(\mathrm{HC}=\mathrm{C}, \mathrm{C}-13), 124.4(\mathrm{HC}=\mathrm{C}, \mathrm{C}-12), 64.6\left(\mathrm{CH}_{2}-\mathrm{O}, \mathrm{C}-23\right), 52.4\left(\mathrm{COOCH}_{3}, \mathrm{C}-31\right), 49.0$ ( $\mathrm{CH}, \mathrm{C}-9), 48.0(\mathrm{CH}, \mathrm{C}-5), 47.4(\mathrm{C}, \mathrm{C}-17), 45.0$ (C, C-20), 43.9 (CH, C-18), $43.9(\mathrm{C}, \mathrm{C}-4)$, $43.3\left(\mathrm{CH}_{2}, \mathrm{C}-19\right), 42.9$ (C, C-14), 40.6 (C, C-8), $39.5\left(\mathrm{CH}_{2}, \mathrm{C}-1\right), 37.7$ (C, C-10), $34.4\left(\mathrm{CH}_{2}\right.$, C-22), $33.4\left(\mathrm{CH}_{2}, \mathrm{C}-7\right), 31.3\left(\mathrm{CH}_{2}, \mathrm{C}-21\right), 29.0\left(\mathrm{CH}_{2}, \mathrm{C}-15\right), 28.6\left(\mathrm{CH}_{3}, \mathrm{C}-29\right), 26.4\left(\mathrm{CH}_{2}, \mathrm{C}-\right.$ 2), $26.3\left(\mathrm{CH}_{3}, \mathrm{C}-27\right), 24.6\left(\mathrm{CH}_{2}, \mathrm{C}-11\right), 24.2\left(\mathrm{CH}_{2}, \mathrm{C}-16\right), 18.8\left(\mathrm{CH}_{2}, \mathrm{C}-6\right), 17.7\left(\mathrm{CH}_{3}, \mathrm{C}-26\right)$, $16.4\left(\mathrm{CH}_{3}, \mathrm{C}-25\right), 13.4\left(\mathrm{CH}_{3}, \mathrm{C}-24\right) ;{ }^{1} \mathrm{H}$ and ${ }^{13} \mathrm{C}$ NMR of the glycosidic part, see Table 2; HRESIMS (positive-ion mode) $\mathrm{m} / z$ 1023.4786 [M+Na] ${ }^{+}$(calculated for $\mathrm{C}_{49} \mathrm{H}_{76} \mathrm{O}_{21} \mathrm{Na}$, 1023.4777). 
4.16. Zebirioside $L$, 3-O- $\beta$-D-xylopyranosyl-(1 $\rightarrow 3)-\alpha-L-r h a m n o p y r a n o s y l-(1 \rightarrow 3)-\beta-D-$ glucuronopyranosyl phytolaccinic acid (12): White powder; $[\alpha]_{D}{ }^{20}+18.3^{\circ}(c 0.18, \mathrm{MeOH}) ;{ }^{1} \mathrm{H}$ NMR $\left(600 \mathrm{MHz}\right.$, Methanol- $\left.d_{4}\right) \delta 5.19(1 \mathrm{H}, \mathrm{t}, J=3.4 \mathrm{~Hz}, \mathrm{H}-12), 3.59(3 \mathrm{H}, \mathrm{s}, \mathrm{H}-31), 3.54(1 \mathrm{H}$, m, H-3), $3.51(1 \mathrm{H}, \mathrm{d}, J=11.7 \mathrm{~Hz}, \mathrm{H \alpha}-23), 3.16(1 \mathrm{H}, \mathrm{d}, J=11.7 \mathrm{~Hz}, \mathrm{H \beta}-23), 2.59(1 \mathrm{H}, \mathrm{dd}, J=$ 13.6, 3.6 Hz, H-18), $2.02(1 \mathrm{H}, \mathrm{dd}, J=13.8,4.1 \mathrm{~Hz}, \mathrm{Ha}-16), 1.89(1 \mathrm{H}, \mathrm{m}, \mathrm{Ha}-21), 1.83(1 \mathrm{H}$, m, Ha-19), 1.81 (2H, dd, J = 8.8, 2.6 Hz, H-11), 1.81 (1H, m, Ha-2), 1.65 (1H, m, Ha-15), $1.64(1 \mathrm{H}, \mathrm{m}, \mathrm{H} \beta-2), 1.57(1 \mathrm{H}, \mathrm{m}, \mathrm{H} \beta-19), 1.54(2 \mathrm{H}, \mathrm{m}, \mathrm{H} \beta-16 / \mathrm{H}-9), 1.52(1 \mathrm{H}, \mathrm{m}, \mathrm{Ha}-7), 1.51$ (2H, m, H-22), 1.50 (1H, m, Ha-1), 1.38 (1H, m, Ha-6), $1.27(1 \mathrm{H}, \mathrm{m}, \mathrm{H \beta}-21), 1.26(1 \mathrm{H}, \mathrm{m}, \mathrm{H} \beta-$ 6), $1.16(1 \mathrm{H}, \mathrm{m}, \mathrm{H} \beta-7), 1.15(1 \mathrm{H}, \mathrm{m}, \mathrm{H}-5), 1.08(3 \mathrm{H}, \mathrm{s}, \mathrm{H}-27), 1.03(3 \mathrm{H}, \mathrm{s}, \mathrm{H}-29), 1.00(1 \mathrm{H}$,

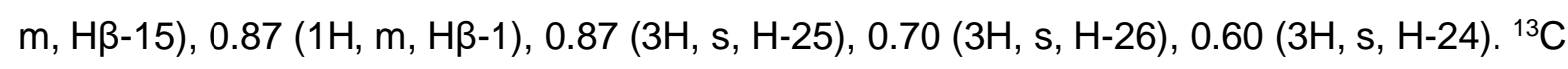
$\operatorname{NMR}\left(151 \mathrm{MHz}, \mathrm{CD}_{3} \mathrm{OD}\right) \delta 181.2(\mathrm{COOH}, \mathrm{C}-28), 178.9\left(\mathrm{COOCH}_{3}, \mathrm{C}-30\right), 144.8(\mathrm{HC}=\mathrm{C}, \mathrm{C}-$ 13), 124.2 ( $\mathrm{HC}=\mathrm{C}, \mathrm{C}-12), 82.8$ ( $\mathrm{CH}-\mathrm{O}, \mathrm{C}-3), 64.5\left(\mathrm{CH}_{2}-\mathrm{O}, \mathrm{C}-23\right), 52.3\left(\mathrm{COOCH}_{3}, \mathrm{C}-31\right), 49.0$ ( $\mathrm{CH}, \mathrm{C}-9), 48.0$ ( $\mathrm{CH}, \mathrm{C}-5), 47.0$ (C, C-17), 45.0 (C, C-20), 44.0 (CH, C-18), 43.9 (C, C-4), $43.3\left(\mathrm{CH}_{2}, \mathrm{C}-19\right), 42.8$ (C, C-14), 40.6 (C, C-8), $39.5\left(\mathrm{CH}_{2}, \mathrm{C}-1\right), 37.6(\mathrm{C}, \mathrm{C}-10), 35.0\left(\mathrm{CH}_{2}\right.$, C-22), $33.4\left(\mathrm{CH}_{2}, \mathrm{C}-7\right), 31.3\left(\mathrm{CH}_{2}, \mathrm{C}-21\right), 28.8\left(\mathrm{CH}_{2}, \mathrm{C}-15\right), 28.7\left(\mathrm{CH}_{3}, \mathrm{C}-29\right), 26.4\left(\mathrm{CH}_{2}, \mathrm{C}-\right.$ 2), $26.3\left(\mathrm{CH}_{3}, \mathrm{C}-27\right), 24.5\left(\mathrm{CH}_{2}, \mathrm{C}-11\right), 24.2\left(\mathrm{CH}_{2}, \mathrm{C}-16\right), 18.8\left(\mathrm{CH}_{2}, \mathrm{C}-6\right), 17.7\left(\mathrm{CH}_{3}, \mathrm{C}-26\right)$, $16.4\left(\mathrm{CH}_{3}, \mathrm{C}-25\right), 13.4\left(\mathrm{CH}_{3}, \mathrm{C}-24\right) ;{ }^{1} \mathrm{H}$ and ${ }^{13} \mathrm{C}$ NMR of the glycosidic part, see Table 2; HRESIMS (positive-ion mode) $\mathrm{m} / z$ 993.4673 [M+Na $]^{+}$(calculated for $\mathrm{C}_{48} \mathrm{H}_{74} \mathrm{O}_{20} \mathrm{Na}, 993.4671$ ).

\subsection{Biological assays}

\subsubsection{Cytotoxicity assay}

Human dermal fibroblasts were isolated from skin biopsies of healthy subjects and were obtained using cell culture medium selection (Gillery et al., 1996). Briefly, the hypodermis was mechanically eliminated and explants were cut into $1 \mathrm{~mm}^{2}$ pieces. Skin fragments were then cultivated at $37^{\circ} \mathrm{C} / 5 \% \mathrm{CO}_{2}$ in $75 \mathrm{~cm}^{2}$ cell culture dishes containing $10 \mathrm{~mL}$ of DMEM medium supplemented with $20 \%$ FCS, $1 \%$ antibiotics (penicillin, streptomycin) and $1 \%$ fungizone. The medium was changed every two days. After 4 weeks of culture, fibroblasts have covered all the surface of the culture dishes and were trypsined. Cells $\left(2.510^{3}\right)$ were cultured in 96 well-culture plates $\left(37^{\circ} \mathrm{C} / 5 \% \mathrm{CO}_{2}\right)$ in DMEM containing $1 \mathrm{~g} / \mathrm{L}$ of glucose, Glutamax I and pyruvate supplemented with $10 \%$ FCS. Subcultures 3 to 5 were used in this study.

Fibroblasts were then stimulated or not with the different compounds (1-14) at the indicated concentrations for $24 \mathrm{~h}$ and their cytotoxicity was evaluated using MTT assay following manufacturer's instructions (Rusciani et al., 2010). a-hederin (5 $\mu \mathrm{g} / \mathrm{mL}$ in DMEM-glutamine) was used as positive control. MTT solution ( $6 \mathrm{mg} / \mathrm{mL}$ in DMSO) was added ( $15 \mu \mathrm{L} /$ well) to the culture medium and the cells were incubated for $4 \mathrm{~h}$ at $37^{\circ} \mathrm{C}$. The culture medium was 
then removed and DMSO (200 $\mu \mathrm{L} /$ well) was added. Absorbance was measured at $540 \mathrm{~nm}$ on a microplate spectrophotometer (Tecan infinite 200). All tests were performed in quadruplicate and results are expressed as inhibition $\%$ at $10 \mu \mathrm{g} / \mathrm{mL}$ or as $\mathrm{IC}_{50}(\mu \mathrm{M})$ when a dose effect was realized.

\subsubsection{Hemolytic assay}

The hemolytic activity of compounds 1-14 on sheep erythrocytes was measured on 96-wellmicroplate as previously reports with slight modifications (Chwalek et al., 2006). $25 \mu \mathrm{L}$ of $10 \%$ sheep erythrocytes (Eurobio) suspension in phosphate-buffered saline (PBS, pH 7.4) was incubated with $500 \mu \mathrm{L}$ of saponins dilutions $(100,75,50,40,30,25,20,10,7.5,5,2.5$ and $1 \mu \mathrm{g} / \mathrm{ml}$ ) in PBS at $37^{\circ} \mathrm{C}$ for $1 \mathrm{~h}$. The mixture was centrifuged ( $3000 \mathrm{rpm}, 5 \mathrm{~min}$ ) and the supernatant $(200 \mu \mathrm{L})$ was transferred to 96 -well microtiter plates. The hemoglobin content was measured at $540 \mathrm{~nm}$ by a multiwall spectrophotometer (FLUO STAR Omega). Commercial saponins (Sigma-Aldrich) was used as positive control on the same conditions and all tests was performed in triplicate.

\subsubsection{Antileishmanial assay}

All molecules were first screened in vitro on the promastigote stage of $L$. infantum by determining their inhibitory concentrations $50 \%\left(\mathrm{IC}_{50}\right)$ and comparing them to the one of amphotericin $\mathrm{B}$, chosen as antileishmanial reference-drug.

Leishmania species used in this study were L. infantum MHOM/MA/67/ITMAP-263 (CNR Leishmania, Montpellier, France) expressing luciferase activity. The effects of the tested compounds on the growth of $L$. infantum promastigotes were assessed by Luciferase Assay. Briefly, promastigotes in log-phase in RPMI 1640 medium supplemented with $10 \%$ fetal calf serum (FCS), $2 \mathrm{mM} \mathrm{L}$-glutamine and antibiotics $(100 \mathrm{U} / \mathrm{mL}$ penicillin, $100 \mu \mathrm{g} / \mathrm{mL}$ streptomycin and $50 \mu \mathrm{g} / \mathrm{mL}$ geneticin), were incubated at an average density of 106 parasites $/ \mathrm{mL}$ in sterile 96-well plates with various concentrations of compounds dissolved in DMSO or $\mathrm{MeOH}$ (final concentration less than $0.5 \% \mathrm{v} / \mathrm{v}$ ), in duplicate. Appropriate controls treated by DMSO, $\mathrm{MeOH}$ and amphotericin $\mathrm{B}$ (reference drug purchased from Sigma Aldrich) were added to each set of experiments. After a $72 \mathrm{~h}$ incubation period at $24^{\circ} \mathrm{C}$, each plate-well was then microscope-examined for detecting possible precipitate formation. To estimate the luciferase activities of promastigotes, $80 \mu \mathrm{L}$ of each well are transferred in white 96-well plates, Steady Glow reagent (Promega) was added according to manufacter's instructions, and plates were incubated for $2 \mathrm{~min}$. The luminescence was measured in Microbeta Luminescence Counter (PerkinEImer). Inhibitory concentration $50 \%\left(\mathrm{IC}_{50}\right)$ was defined as the concentration of drug required to inhibit by $50 \%$ 
the metabolic activity of $L$. infantum promastigotes compared to the control. $\mathrm{IC}_{50}$ were calculated by non-linear regression analysis processed on dose-response curves, using TableCurve 2D V5 software. $\mathrm{IC}_{50}$ values represent the mean value calculated from three independent experiments.

\section{Acknowledgment.}

Financial support by CNRS, Conseil Regional Champagne Ardenne, Conseil General de la Marne, Ministry of Higher Education and Research (MESR) and EU-programme FEDER to the PIAneT CPER project is gratefully acknowledged.

\section{References}

Agrawal, P. K., 1992. NMR spectroscopy in the structural elucidation of oligosaccharides and glycosides. Phytochemistry 31, 3307-3330.

Bader, G., Plohmann, B., Hiller, K., Franz, G., 1996. Cytotoxicity of triterpenoid saponins. Part 1. Activities against tumor cells in vitro and hemolytic index. Pharmazie 51, 414-417.

Bock, K., Pedersen, C., 1983 Carbon-13 Nuclear Magnetic Resonance Spectroscopy of Monosaccharides. In: Horton, R. S. T. a. D. (Ed.), Advances in Carbohydrate Chemistry and Biochemistry vol. 41. Academic Press, pp. 27-66.

Chwalek, M., Lalun, N., Bobichon, H., Ple, K., Voutquenne-Nazabadioko, L., 2006. Structureactivity relationships of some hederagenin diglycosides: Haemolysis, cytotoxicity and apoptosis induction. Biochim. Biophys. Acta, Gen. Subj. 1760, 1418-1427.

De Stefano, R. D., 2007. Tratamiento taxonómico del género Dendrobangia Rusby Cardiopteridaceae o Icacinaceae. Candollea 62, 91-103.

Gillery, P., Georges, N., Randoux, A., Lefevre, F., Maquart, F.-X., Borel, J.-P., 1996. Modulation of protein synthesis by extracellular matrix: potential involvement of two nucleolar proteins, nucleolin and fibrillarin. Biochem. Biophys. Res. Commun. 228, 9499.

Jayasinghe, U. L. B., Wannigama, G. P., Macleod, J. K., 1998. Glucuronides of Diploclisia glaucescens. J. Chem. Soc. Pak. 20, 131-137.

Johnson, A., Shimizu, Y., 1974. Phytolaccinic acid, a new triterpene from Phytolacca americana. Tetrahedron 30, 2033-2036.

Karehed, J., 2001. Multiple origin of the tropical forest tree family Icacinaceae. Am J Bot 88, 2259-2274.

Kohda, H., Yamaoka, Y., Morinaga, S., Ishak, M., Darise, M., 1992. Saponins from Talinum triangulare. Chem. Pharm. Bull. 40, 2557-2558.

Mahato, S. B., Kundu, A. P., 1994. Review article number 98: 13C NMR spectra of pentacyclic triterpenoids - a compilation and some salient features. Phytochemistry 37, 15171575.

Montoya Pelaez, G. L., Sierra, J. A., Alzate, F., Holzgrabe, U., Ramirez-Pineda, J. R., 2013. Pentacyclic triterpenes from Cecropia telenitida with immunomodulatory activity on dendritic cells. Rev. Bras. Farmacogn. 23, 754-761. 
Rusciani, A., Duca, L., Sartelet, H., Chatron-Colliet, A., Bobichon, H., Ploton, D., Le Naour, R., Blaise, S., Martiny, L., Debelle, L., 2010. Elastin Peptides Signaling Relies on Neuraminidase-1-Dependent Lactosylceramide Generation. PloS one 5, e14010. 


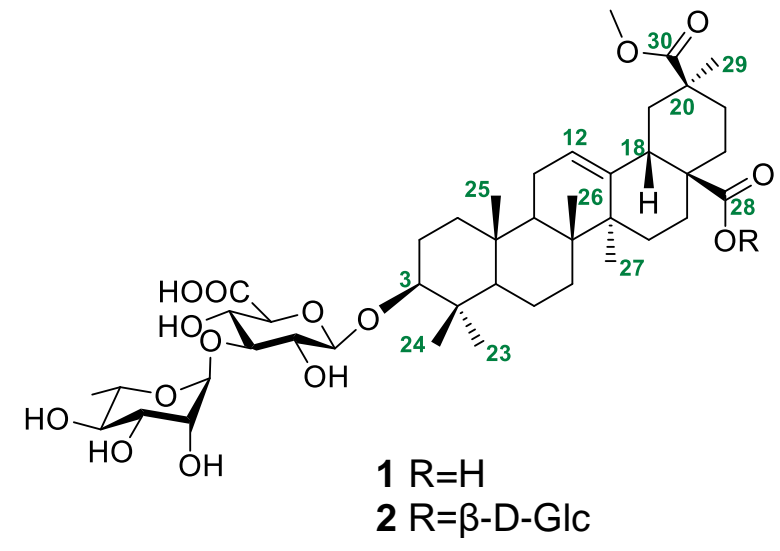

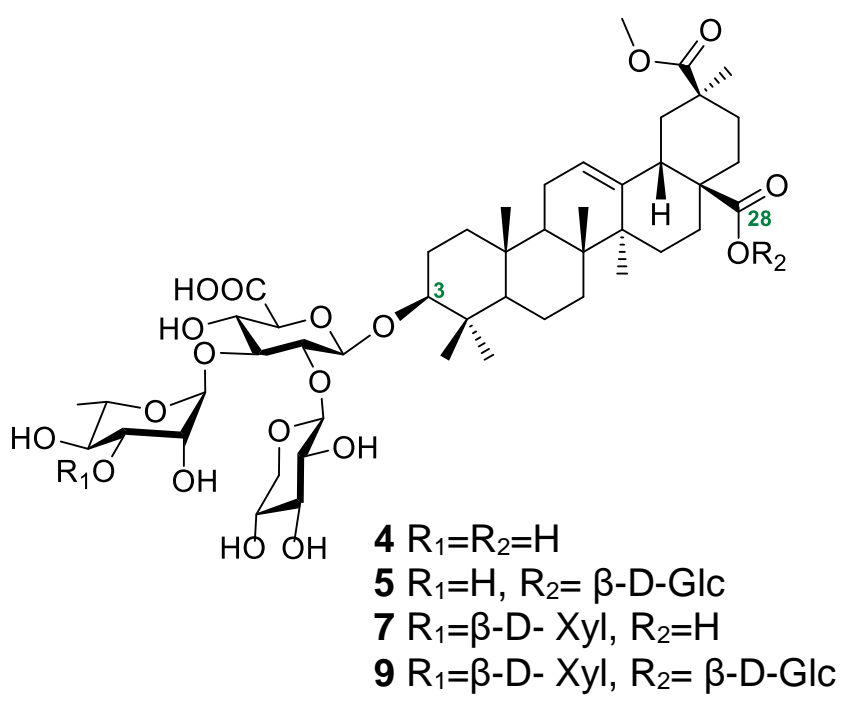
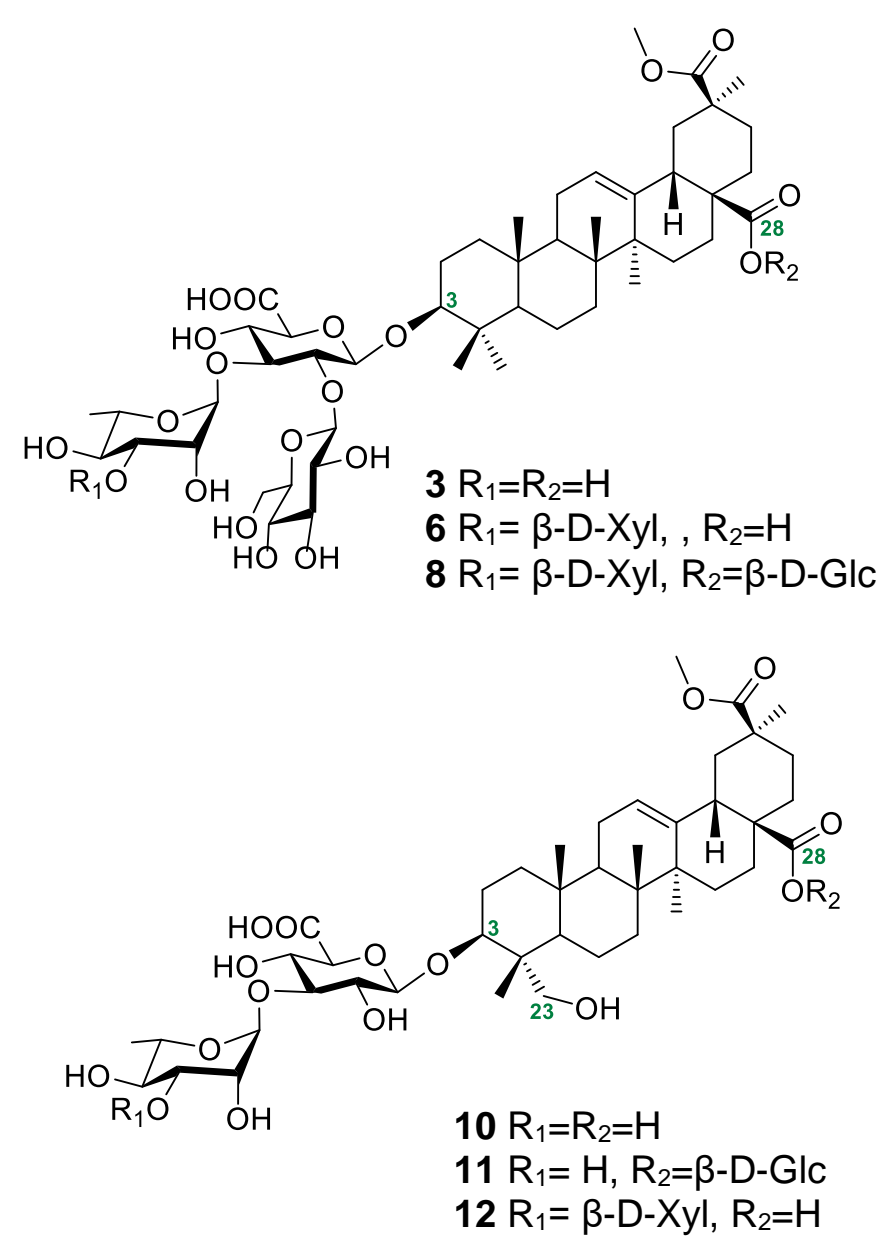

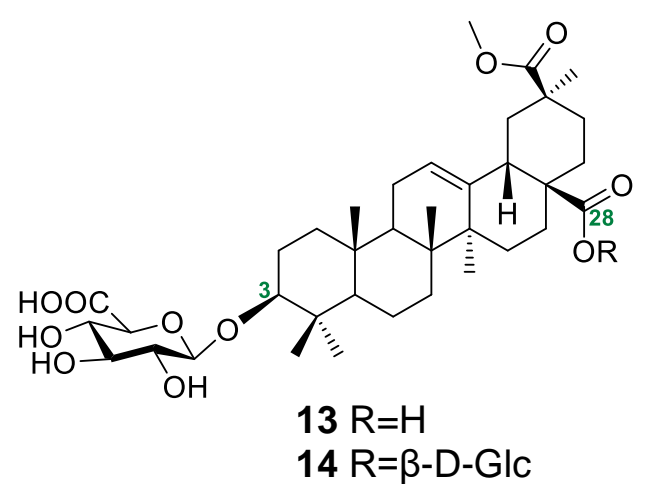

Figure 1: structures of compounds 1-14 
Table 1. ${ }^{1} \mathrm{H}(600 \mathrm{MHz})$ and ${ }^{13} \mathrm{C}(151 \mathrm{MHz})$ NMR spectral data $(\delta$ in ppm) of osidic parts of saponins 1-6 (MeOD)

\begin{tabular}{|c|c|c|c|c|c|c|c|c|c|c|c|c|}
\hline \multirow{3}{*}{$\begin{array}{l}3-O- \\
\beta-D-G \mid c\end{array}$} & \multicolumn{2}{|l|}{1} & \multicolumn{2}{|l|}{2} & \multicolumn{2}{|l|}{3} & \multicolumn{2}{|l|}{4} & \multicolumn{2}{|l|}{5} & \multicolumn{2}{|l|}{6} \\
\hline & \multirow{2}{*}{\multicolumn{2}{|c|}{$\delta \mathrm{H}(\mathrm{m}, J(\mathrm{~Hz}))$}} & \multirow[t]{2}{*}{$\delta \mathrm{H}(\mathrm{m}, J(\mathrm{~Hz}))$} & \multirow[t]{2}{*}{$\delta C$} & \multirow[t]{2}{*}{$\delta \mathrm{H}(\mathrm{m}, J(\mathrm{~Hz}))$} & \multirow[t]{2}{*}{$\delta c$} & \multirow[t]{2}{*}{$\delta \mathrm{H}(\mathrm{m}, J(\mathrm{~Hz}))$} & \multirow[t]{2}{*}{$\delta C$} & \multirow[t]{2}{*}{$\delta \mathrm{H}(\mathrm{m}, \mathrm{J}(\mathrm{Hz}))$} & \multirow[t]{2}{*}{$\delta c$} & \multirow[t]{2}{*}{$\delta \mathrm{H}(\mathrm{m}, J(\mathrm{~Hz}))$} & \multirow[t]{2}{*}{$\delta c$} \\
\hline & & & & & & & & & & & & \\
\hline & $14.41(\mathrm{~d}, 7.9)$ & 106.8 & $4.59(\mathrm{~d}, 7.7)$ & 106.8 & $4.58(d, 7.7)$ & 105.3 & $4.42(d, 7.8)$ & 105.5 & $4.57(d, 7.7)$ & 106.5 & $4,54(d, 7.1)$ & 105,4 \\
\hline & $23.36(t, 8.2)$ & 75.9 & $3.36(\mathrm{~m})$ & 76.0 & $3.80(\mathrm{dd}, 8.8-7.7)$ & 78.1 & $3.54(\mathrm{~m})$ & 79.2 & $3.80(\mathrm{dd}, 8.9-7.7)$ & 77.8 & $3,67(\mathrm{~m})$ & 78,8 \\
\hline & $33.53(t, 9.0)$ & 83.4 & $3.53(t, 8.9)$ & 83.4 & $3.72(\mathrm{dd}, 9.6-8.8)$ & 86.0 & $3.58(\mathrm{~m})$ & 86.2 & $3.82(\mathrm{t}, 8.9)$ & 81.6 & $3,71(\mathrm{~m})$ & 87 \\
\hline & $43.57(t, 9.1)$ & 71.8 & $3.58(t, 9.1)$ & 71.9 & $3.65(t, 9.3)$ & 72.0 & $3.52(\mathrm{~m})$ & 72.0 & $3.65(t, 9.0)$ & 72.2 & $3,66(m)$ & 72,1 \\
\hline & $53.82(d, 6.3)$ & 76.6 & $3.82(d, 9.5)$ & 76.6 & $3.86(d, 9.3)$ & 76.7 & $3.72(\mathrm{~m})$ & 76.4 & $3.79(\mathrm{~m})$ & 76.8 & $3,83(\mathrm{~m})$ & 76,6 \\
\hline & 6 & 172.5 & & 172.6 & & 172.3 & & 172.3 & & 173.3 & & 172,5 \\
\hline \multicolumn{13}{|c|}{$\alpha$-L-Rha } \\
\hline & $15.19(\mathrm{~d}, 1.7)$ & 102.8 & $5.19(d, 1.5)$ & 102.8 & $5.07(\mathrm{~d}, 1.9)$ & 103.5 & $4.94(d, 1.9)$ & 103.5 & $5.04(d, 1.9)$ & 103.5 & $5.03(d, 1.9)$ & 103,4 \\
\hline & $23.96(\mathrm{dd}, 3.3-1.7)$ & 72.4 & $3.96(\mathrm{dd}, 3.3-1.5)$ & 72.4 & $4.06(\mathrm{dd}, 3.4-1.9)$ & 72.2 & $3.96(\mathrm{dd}, 3.4-1.9)$ & 72.2 & $4.29(\mathrm{dd}, 3.2-1.9)$ & 71.8 & $4.29(\mathrm{dd}, 3.2-1.9)$ & 71,8 \\
\hline & 33.71 (dd, 9.5-3.3) & 72.3 & $3.71(\mathrm{dd}, 9.5-3.3)$ & 72.3 & $3.70(\mathrm{dd}, 9.5-3.4)$ & 72.3 & $3.57(\mathrm{~m})$ & 72.2 & $3.82(\mathrm{dd}, 9.4-3.2)$ & 81.5 & $3.81(\mathrm{dd}, 9.5-3.2)$ & 81,6 \\
\hline & $43.40(t, 9.5)$ & 74.0 & $3.41(t, 9.6)$ & 74.0 & $3.44(t, 9.5)$ & 73.7 & $3.32(t, 9.5)$ & 73.8 & $3.61(t, 9.4)$ & 72.8 & $3.62(\mathrm{t}, 9.5)$ & 72,8 \\
\hline & 54.02 (dq, 9.5-6.2) & 69.9 & $4.02(d q, 9.6-6.2)$ & 70.0 & $3.96(d q, 9.6-6.3)$ & 70.7 & $3.82(d q, 9.5-6.2)$ & 70.7 & $4.02(\mathrm{~m})$ & 70.5 & $3.98(\mathrm{~m})$ & 70,5 \\
\hline & 61.25 (d, 6.2) & 17.8 & $1.25(\mathrm{~d}, 6.2)$ & 17.9 & $1.23(\mathrm{t}, 6.3)$ & 17.8 & $1.15(t, 6.2)$ & 17.9 & $1.28(\mathrm{~d}, 6.2)$ & 17.9 & $1.28(\mathrm{~d}, 6.2)$ & 17,9 \\
\hline \multicolumn{13}{|c|}{$\beta$-D-Xyl 1} \\
\hline & 1 & & & & & & $4.40(\mathrm{~d}, 7.8)$ & 104.8 & $4.57(\mathrm{~d}, 7.4)$ & 105.4 & $4,52(d, 7.6)$ & 104,8 \\
\hline & 2 & & & & & & $3.08(\mathrm{dd}, 9.3-7.7)$ & 75.6 & $3.31(\mathrm{~m})$ & 75.3 & $3,20(\mathrm{dd}, 9.3-7.6)$ & 75,5 \\
\hline & 3 & & & & & & $3.21(\mathrm{~m})$ & 77.9 & $3.37(\mathrm{t}, 8.5)$ & 77.6 & $3,33(\mathrm{~m})$ & 77,9 \\
\hline & 4 & & & & & & 3.34 (ddd, 10.4-8.8-5. & 71.3 & 3.51 (ddd, 10.2-8.5-5.3) & 71.2 & $3,47$ (ddd, $10.4-8.8-5,4)$ & 71,3 \\
\hline & 5 & & & & & & $3.02(\mathrm{dd}, 11.5-10.4)$ & 670 & 3.14 (dd, 11.4-10.2) & 670 & 3.14 (dd, 11.4-10.4) & 670 \\
\hline & 5 & & & & & & $3.71(\mathrm{dd}, 11.5-5.4)$ & $6 \% .0$ & $3.83(\mathrm{dd}, 11.4-5.3)$ & 67.0 & $3.84(\mathrm{dd}, 11.4-5.4)$ & $6 /, 0$ \\
\hline \multicolumn{13}{|l|}{$\beta$-D-Glc } \\
\hline & 1 & & & & $4.62(d, 7.7)$ & 103.7 & & & $4.63(d, 7.8)$ & 103.8 & & \\
\hline & 2 & & & & $3.22(\mathrm{dd}, 9.9-7.3)$ & 75.6 & & & $3.21(\mathrm{dd}, 9.1-7.8)$ & 75.5 & & \\
\hline & 3 & & & & $3.38(t, 9.1)$ & 77.8 & & & $3.40(t, 9.1)$ & 77.9 & & \\
\hline & 4 & & & & $3.10(\mathrm{dd}, 9.6-9.0)$ & 72.4 & & & $3.11(\mathrm{dd}, 9.6-9.1)$ & 72.4 & & \\
\hline & 5 & & & & 3.28 (ddd, 9.6-7.8-2. & $=78.6$ & & & $3.28(\mathrm{~m})$ & 78.8 & & \\
\hline & 6 & & & & 3.57 (dd, 12.1-7.8) & 63.5 & & & $3.57(\mathrm{dd}, 12.1-7.9)$ & 63.6 & & \\
\hline & & & & & $3.86(\mathrm{dd}, 12.1-2.3)$ & & & & $3.87(\mathrm{dd}, 12.1-2.4)$ & & & \\
\hline$\beta-D-X y 1$ & & & & & & & & & & & & \\
\hline & 1 & & & & & & & & & & $4,56(d, 7.5)$ & 106,5 \\
\hline & 2 & & & & & & & & & & $3,31(\mathrm{dd}, 9.3-7.5)$ & 75,3 \\
\hline & 3 & & & & & & & & & & $3,36(\mathrm{~m})$ & 77,6 \\
\hline & 4 & & & & & & & & & & $3,51$ (ddd, $10.4-8.8-5,4)$ & 71,2 \\
\hline & 5 & & & & & & & & & & $\begin{array}{l}3.28(\mathrm{dd}, 11.4-10.2) \\
3.99(\mathrm{dd}, 11.4-5.4)\end{array}$ & 67,00 \\
\hline 28-0- & $\beta-$ & & & & & & & & & & & \\
\hline & 1 & & $5.36(d, 8.2)$ & 95.8 & & & & & & & & \\
\hline & 2 & & 3.32 (dd, 9.0-8.2) & 73.9 & & & & & & & & \\
\hline & 3 & & $3.42(t, 9.0)$ & 78.3 & & & & & & & & \\
\hline & 4 & & $3.36(\mathrm{~m})$ & 71.1 & & & & & & & & \\
\hline & 5 & & $3.35(\mathrm{~m})$ & 78.8 & & & & & & & & \\
\hline & 6 & & 3.69 (dd, 12.3-4.4) & 62.3 & & & & & & & & \\
\hline
\end{tabular}


Table 2. ${ }^{1} \mathrm{H}(600 \mathrm{MHz})$ and ${ }^{13} \mathrm{C}(151 \mathrm{MHz})$ NMR spectral data $(\delta$ in ppm) of osidic parts of saponins 7-12 (MeOD)

\begin{tabular}{|c|c|c|c|c|c|c|c|c|c|c|c|c|}
\hline \multirow{3}{*}{$\begin{array}{l}3-O- \\
\beta-D-G \mid c A\end{array}$} & \multicolumn{2}{|l|}{7} & \multicolumn{2}{|l|}{8} & \multicolumn{2}{|l|}{9} & \multicolumn{2}{|l|}{10} & \multicolumn{2}{|l|}{11} & \multicolumn{2}{|l|}{12} \\
\hline & $\delta \mathrm{H}(\mathrm{m}, J(\mathrm{~Hz}))$ & $\delta c$ & $\delta \mathrm{H}(\mathrm{m}, J(\mathrm{~Hz}))$ & $\delta c$ & $\delta \mathrm{H}(\mathrm{m}, J(\mathrm{~Hz}))$ & $\delta c$ & $\delta \mathrm{H}(\mathrm{m}, J(\mathrm{~Hz}))$ & $\delta C$ & $\delta \mathrm{H}(\mathrm{m}, J(\mathrm{~Hz}))$ & $\delta C$ & $\delta \mathrm{H}(\mathrm{m}, J(\mathrm{~Hz}))$ & $\delta C$ \\
\hline & & & & & & & & & & & & \\
\hline & $14.53(d, 7.3)$ & 105.5 & $3.59(d, 7.7)$ & 105.3 & $4.54(d, 7.0)$ & 105.4 & $4.36(d, 7.9)$ & 105.9 & $4.48(d, 8.0)$ & 105.9 & $4.35(d, 8.1)$ & 105.4 \\
\hline & $23.67(\mathrm{~m})$ & 79.1 & $3.81(\mathrm{~m})$ & 77.7 & $3.67(\mathrm{~m})$ & 78.8 & $3.22(\mathrm{~m})$ & 75.8 & $3.34(t, 9.0)$ & 75.9 & $3.24(\mathrm{~m})$ & 75.8 \\
\hline & $33.69(\mathrm{~m})$ & 86.2 & $3.72(t, 9.0)$ & 86.9 & $3.70(\mathrm{~m})$ & 86.9 & $3.42(\mathrm{~m})$ & 83.4 & $3.54(\mathrm{~m})$ & 83.2 & $3.44(\mathrm{~m})$ & 83.1 \\
\hline & $43.65(t, 9.6)$ & 72.0 & $3.67(t, 9.0)$ & 72.1 & $3.66(\mathrm{~m})$ & 72.0 & $3.44(\mathrm{~m})$ & 71.9 & $3.57(t, 9.1)$ & 71.8 & $3.42(\mathrm{~m})$ & 72.2 \\
\hline & $53.83(\mathrm{~m})$ & 76.4 & $3.85(\mathrm{~m})$ & 76.6 & $3.84(\mathrm{~m})$ & 76.3 & $3.71(d, 7.4)$ & 76.7 & $3.89(t, 9.5)$ & 76.7 & $3.83(\mathrm{~m})$ & nd \\
\hline & 6 & 172.5 & & 172.6 & & 172.6 & & 172.7 & & 172.5 & & nd \\
\hline \multicolumn{13}{|l|}{$\alpha-L-R h a$} \\
\hline & $15.06(d, 1.9)$ & 103.5 & $5.04(d, 1.9)$ & 103.5 & $5.03(d, 1.8)$ & 103.4 & $5.07(\mathrm{~d}, 1.2)$ & 102.7 & $5.19(d, 1.3)$ & 102.8 & $5.10(d, 1.37)$ & 102.3 \\
\hline & 24.07 (dd, 3.6-1.9) & 72.2 & $4.29(\mathrm{dd}, 3.0-1.9)$ & 71.9 & $4.29(\mathrm{dd}, 3.0-1.8)$ & 71.8 & $3.83(\mathrm{dd}, 3.6-1.2)$ & 72.4 & $3.96(\mathrm{dd}, 1.3-3.3)$ & 72.3 & $4.02(\mathrm{~m})$ & 72.0 \\
\hline & $33.68(\mathrm{~m})$ & 72.1 & $3.82(\mathrm{~m})$ & 81.5 & $3.81(\mathrm{~m})$ & 81.6 & $3.60(\mathrm{dd}, 9.5-3.6)$ & 72.3 & $3.71(\mathrm{~m})$ & 72.2 & $3.71(\mathrm{dd}, 9.5-3.1)$ & 82.3 \\
\hline & $43.43(\mathrm{~m})$ & 73.8 & $3.62(t, 9.5)$ & 72.8 & $3.62(t, 9.5)$ & 72.8 & $3.28(d, 9.5)$ & 74.0 & $3.40(t, 9.6)$ & 74.0 & $3.45(t, J=9.6)$ & 72.9 \\
\hline & $53.94(\mathrm{dq}, 9.5-6.2)$ & 70.6 & $3.40(\mathrm{~m})$ & 70.5 & $3.98(\mathrm{~m})$ & 70.5 & $3.90(d q, 9.5-6.2)$ & 70.0 & 4.01 (dq, 9.5-6.2) & 70.0 & $4.02(\mathrm{~m})$ & 69.6 \\
\hline & $61.27(\mathrm{t}, 6.2)$ & 17.8 & $1.28(\mathrm{t}, 6.3)$ & 17.9 & $1.28(\mathrm{t}, 6.2)$ & 17.9 & $1.13(d, 6.2)$ & 17.7 & $1.25(\mathrm{t}, 6.2)$ & 17.8 & $1.13(t, 6.2)$ & 17.9 \\
\hline \multicolumn{13}{|l|}{$\beta$-D-Xyl 1} \\
\hline & $14.52(d, 7.6)$ & 104.7 & $4.57(d, 7.5)$ & 106.5 & $4.56(d, 7.5)$ & 106.5 & & & & & $4.39(d, 7.2)$ & 106.5 \\
\hline & $23.20(\mathrm{~m})$ & 75.6 & $3.31(\mathrm{~m})$ & 75.3 & $3.31(\mathrm{~m})$ & 75.3 & & & & & 3.18 & 75.3 \\
\hline & $33.33(\mathrm{~m})$ & 77.9 & $3.37(\mathrm{~m})$ & 77.6 & $3.37(\mathrm{~m})$ & 77.6 & & & & & 3.22 & 77.6 \\
\hline & $43.46(\mathrm{~m})$ & 71.3 & 3.51 (ddd, 10.1-8.8-5. & 51.2 & 3.51 (ddd, 10.2-9.1 & 5.71 .2 & & & & & 3.38 (ddd, 10.2-8.4-5.3) & 71.1 \\
\hline & $53.14(\mathrm{~m})$ & 66.9 & $3.29(\mathrm{~m})$ & 67.1 & $3.28(\mathrm{~m})$ & 67.0 & & & & & $3.11(\mathrm{dd}, 11.4-10.1)$ & 66.8 \\
\hline & $3.83(\mathrm{~m})$ & 6.9 & $4,01(m)$ & $6 / .1$ & $3.98(\mathrm{~m})$ & $6 \% .0$ & & & & & $3.75(\mathrm{dd}, 11.4-5.3)$ & \\
\hline \multicolumn{13}{|l|}{$\beta$-D-GIC } \\
\hline & 1 & & $4.63(d, 7.7)$ & 103.8 & & & & & & & & \\
\hline & 2 & & $3.23(\mathrm{dd}, 9.3-7.7)$ & 75.5 & & & & & & & & \\
\hline & 3 & & $3.41(\mathrm{~m})$ & 77.9 & & & & & & & & \\
\hline & 4 & & $3.10(t, 9.2)$ & 72.4 & & & & & & & & \\
\hline & 5 & & $3.28(\mathrm{~m})$ & 78.8 & & & & & & & & \\
\hline & 6 & & 3.57 (dd, 12.3-8,2) & 636 & & & & & & & & \\
\hline & & & $3.87(\mathrm{dd}, 12.3-2.4)$ & 03.0 & & & & & & & & \\
\hline \multicolumn{13}{|c|}{$\beta$-D-Xyl 2} \\
\hline & 1 & & & & $4.52(d, 7.6)$ & 104.8 & & & & & & \\
\hline & 2 & & & & $3.19(\mathrm{~m})$ & 75.5 & & & & & & \\
\hline & 3 & & & & $3.33(\mathrm{~m})$ & 77.9 & & & & & & \\
\hline & 4 & & & & 3.47 (ddd, 10,1-9.3 & 5.71 .4 & & & & & & \\
\hline & 5 & & & & $3.14(\mathrm{~m})$ & 67.0 & & & & & & \\
\hline & & & & & $3.84(\mathrm{~m})$ & (3.0 & & & & & & \\
\hline \multirow{2}{*}{\multicolumn{11}{|c|}{ D-Glc }} & & \\
\hline & $15.36(\mathrm{~d}, 8.2)$ & & $5.36(d, 8.2)$ & & & & & & & & & \\
\hline & $23.32(\mathrm{~m})$ & 73.9 & $3.32(\mathrm{~m})$ & 73.9 & $3.32(\mathrm{~m})$ & 73.9 & & & $3.32(\mathrm{dd}, 9.1-8.0)$ & 73.9 & & \\
\hline & $33.41(\mathrm{~m})$ & 78.3 & $3.41(t, 9.0)$ & 78.3 & $3.41(t, 8.5)$ & 78.3 & & & $3.41(\mathrm{~m})$ & 78.3 & & \\
\hline & $43.36(\mathrm{~m})$ & 71.0 & $3.35(\mathrm{~m})$ & 71.1 & $3.35(\mathrm{~m})$ & 71.1 & & & $3.36(\mathrm{~m})$ & 71.0 & & \\
\hline & $53.35(\mathrm{~m})$ & 78.7 & $3.35(\mathrm{~m})$ & 78.8 & $3.35(\mathrm{~m})$ & 78.8 & & & $3.35(\mathrm{~m})$ & 78.7 & & \\
\hline & $63.70(\mathrm{~m})$ & 62.3 & 3.69 (dd, 12.2-4.6) & 62.3 & $3.69(\mathrm{~m})$ & 62.3 & & & 3.69 (dd, 11.7-4.3) 3.82 & 62.3 & & \\
\hline & $3.83(\mathrm{~m})$ & Oz.J & $3.83(\mathrm{dd}, 12.2-2.0)$ & 0.J & $3.83(\mathrm{~m})$ & (2.J & & & $(\mathrm{dd}, 11.7-2.0)$ & & & \\
\hline
\end{tabular}


Table 3.

Inhibition percentage of cell proliferation (fibroblasts) of saponins 1-14 at $10 \mu \mathrm{g} / \mathrm{mL}$ and $\mathrm{IC}_{50}$

\begin{tabular}{c|c||c|c||c|c} 
Compound & \multicolumn{1}{c||}{ Inhibition \% } & Compound & \multicolumn{1}{c||}{ Inhibition \% } & Compound & \multicolumn{1}{c}{ IC $_{\mathbf{5 0}}(\mu \mathrm{M})$} \\
\hline $\mathbf{1}$ & 0 & $\mathbf{8}$ & 0 & $\mathbf{3}$ & 5.6 \\
$\mathbf{2}$ & 14.0 & $\mathbf{9}$ & 47.1 & $\mathbf{9}$ & 6.4 \\
$\mathbf{3}$ & 54.8 & $\mathbf{1 0}$ & 12.4 & & \\
$\mathbf{4}$ & 17.6 & $\mathbf{1 1}$ & 6.3 & & \\
$\mathbf{5}$ & 9.5 & $\mathbf{1 2}$ & 12.5 & & \\
$\mathbf{6}$ & 39.2 & $\mathbf{1 3}$ & 8.9 & & \\
$\mathbf{7}$ & 23.9 & $\mathbf{1 4}$ & 15.3 & & \\
\hline $\boldsymbol{\alpha}$-hederin & $71.3(\mathbf{5} \boldsymbol{\mu g} / \mathbf{m L})$ & & & a-hederin & 4.6 \\
\hline
\end{tabular}

